ÉGYPTE monde arabe

\section{Égypte/Monde arabe}

$2 \mid 1990$

Médiateur et métaphores 1

\title{
Le soufisme égyptien contemporain
}

\section{Pierre-Jean Luizard}

\section{Q OpenEdition \\ Journals}

Édition électronique

URL : https://journals.openedition.org/ema/218

DOI : 10.4000/ema.218

ISSN : 2090-7273

\section{Éditeur}

CEDEJ - Centre d'études et de documentation économiques juridiques et sociales

\section{Édition imprimée}

Date de publication : 30 juin 1990

Pagination : 35-94

ISSN : 1110-5097

\section{Référence électronique}

Pierre-Jean Luizard, « Le soufisme égyptien contemporain », Égypte/Monde arabe [En ligne], 2 | 1990,

mis en ligne le 08 juillet 2008, consulté le 07 juillet 2022. URL : http://journals.openedition.org/ema/ 218 ; DOl : https://doi.org/10.4000/ema.218

Ce document a été généré automatiquement le 7 juillet 2022.

Tous droits réservés 


\title{
Le soufisme égyptien contemporain
}

\author{
Pierre-Jean Luizard
}

1 Depuis les premiers temps de l'islam, le soufisme, dont la fin ultime est de permettre au fidèle d'unir son âme à Dieu, a suscité des discussions passionnées sur la possibilité et la nature de cette union. Comment le Dieu transcendant, auquel rien n'est semblable, pourrait-il s'unir de quelque manière à la créature ? Parfois, ces polémiques tournaient à la persécution. Toutefois, depuis les $\mathrm{XII}^{\mathrm{e}}$-XIII ${ }^{\mathrm{e}}$ siècles au moins, et jusqu'à ce que le réformisme n'impose sa propre lecture des textes sacrés, il était admis qu'il faut joindre, à la science religieuse qui règle la vie extérieure, le savoir qui permet au croyant de découvrir sa spiritualité intérieure et de s'avancer sur la voie (tariqa) de l'union à Dieu. Le soufisme, qui porte à son paroxysme la tension entre l'observance de la Loi divine, la charî'a, et la réalité profonde, la haqîa a, remplit ce rôle. Là où la charî́a fait appel à l'obéissance et à la stricte observance des rites, le soufisme fait appel à l'amour. C'est l'éternelle opposition entre les défenseurs de la lettre des textes sacrés et ceux qui préfèrent s'inspirer de leur esprit. L'islam n'est pas seul à connaître ce dilemme, caractéristique de toutes les religions révélées par l'écriture. Ainsi, les discussions sur la légitimité du soufisme et de ses pratiques, qui étaient relativement rares dans l'Égypte du XIXe siècle, connaissent un regain de vigueur depuis le début du $\mathrm{xx}^{\mathrm{e}}$ siècle jusqu'à nos jours sous l'influence de la critique réformiste et rationalisante, particulièrement de celle des fondamentalistes de tous bords. Au XIX ${ }^{e}$ siècle en Égypte, nous rappelle Gilbert Delanoue, il est vain de se demander si le soufisme est ou non en conformité avec l'orthodoxie musulmane: il n'existait alors plus d'islam, officiel ou populaire, qui ne soit imprégné de soufisme. L'adhésion à la voie soufie s'imposait à tous, ulémas comme simples fidèles, comme la réalisation la plus spirituelle de la vie religieuse ${ }^{1}$.

Un soufisme confrérique, principal vecteur de la piété populaire

2 Le soufisme désigne l'ensemble des courants de la mystique musulmane. Les confréries soufies se dénomment elles-mêmes par l'expression turuq sûfiyya et le mot tasawwuf (faire profession de soufisme) leur est couramment appliqué. Pourtant, il conviendrait de préciser le sens des mots. Le terme sûfí confond le mystique et le membre d'une confrérie soufie. Or, historiquement, les confréries ne résument pas tout le soufisme et, 
même de nos jours, le soufisme ne résume pas toute la mystique musulmane. Chaykh Muhammad Mitwallî al-Cha'râwi, le célèbre prédicateur qui domine aujourd'hui le monde des prônes, peut être aussi bien considéré comme un mystique, alors qu'il ne se considère pas comme adepte du soufisme.

3 Les confréries n'occupent pas tout l'espace du soufisme. Tarîqa signifiant chemin vers Dieu, il peut donc s'agir d'une simple école sans confrérie. De plus, au fil des siècles, les confréries soufies se sont irrémédiablement compromises avec la piété populaire, au point qu'on pourrait difficilement reconnaître les enseignements des maîtres dans ceux des confréries actuelles. Qui assiste aujourd'hui, dans le delta du Nil, aux gigantesques mawlid de Tanta ou de Disûq, bruyantes fêtes foraines où les stands de tir côtoient les auto-tamponneuses, les grandes roues, les boutiques de traditionnels halwânî, les friandises, et faskhân̂̂, poissons sèchés, aura certes du mal à rattacher ces manifestations à la passion solitaire du grand mystique al-Hallâdj, crucifié à Baghdad en 922 pour n'avoir pas voulu renier l'illumination divine dont il se disait le bénéficiaire. D'aucuns diront que le soufisme est mort avec l'institution des confréries soufies. Où commence la mystique, où finit-elle? Puisque le soufisme égyptien est aujourd'hui inséparable de l'organisation confrérique et qu'il canalise aujourd'hui une grande partie de la piété populaire, c'est, faute de mieux, pour désigner les confréries dont il est question ici, que nous utiliserons le mot « soufi ».

4 La plupart des confréries ne se sont manifestées en Égypte comme confréries distinctes que récemment, notamment depuis la seconde moitié du XIX ${ }^{e}$ siècle. Elles sont autant de ramifications et de subdivisions des six grands ordres soufis qui se répartissent aujourd'hui la mystique égyptienne organisée. (Voir, en annexe, la liste des confréries officielles en 1990). Parmi les plus illustres figurent les ordres fondés par ceux qu'on désigne comme al-aqtâb al-arba'a, les quatre pôles. Il s'agit de la Ahmadiyya, de la Burhamiyya, ainsi que de la Rifâ'yya et de la Qadiriyya, qui montrent toutes une continuité d'organisation remontant à l'époque mamelouke. A ces ordres, il faut ajouter la Chadhiliyya et la Khalwatiyya, et, dans une mesure beaucoup moindre, la Naqchabandiyya. Seules deux de ces confréries sont nées en Égypte; ordres ruraux basés originellement dans le delta, Ahmadiyya et Burhamiyya ont, par la suite, connu un développement extraordinaire qui leur assure une présence sur l'ensemble du territoire égyptien.

5 La confrérie Ahmadiyya se réfère à Ahmad al-Badâwî (1200-1276), qui fut pendant longtemps considéré comme le saint le plus vénéré d'Égypte. Durant l'invasion croisée conduite par Saint-Louis au XIII ${ }^{\mathrm{e}}$ siècle, il joua un rôle important dans l'organisation de la résistance musulmane. Dans la conscience populaire, il demeure celui qui libéra de nombreux prisonniers musulmans tombés aux mains des Croisés. C'est son successeur, chaykh 'Abd al-'Al al-Fichâwî, qui fit bâtir une mosquée sur son tombeau à Tanta, lieu qui devint l'un des pèlerinages les plus fréquentés d'Égypte. Dans leurs pratiques, les confréries se réclamant de la Ahmadiyya ont intégré certains éléments de la religion égyptienne pré-islamique. La confrérie, qui s'est scindée en un nombre sans fin de loges locales, allait devenir le plus important des ordres soufis populaires ruraux d'Égypte².

6 La Burhâmiyya est liée à la personne d'Ibrâhîm ad-Disûqî (1246-1288), enterré à Disûq, aujourd'hui lieu de pèlerinage le plus visité d'Égypte avec Tanta.

7 Autre ordre important en Égypte, la Châdhiliyya est ainsi nommée d'après son fondateur présumé Abu-l-Hasan al-Châdhli (1136-1258). Originaire de Tlemcen, ce dernier ne semble pas avoir laissé d'instructions concernant la fondation d'une 
confrérie ou un rituel particulier. Son enseignement était tout à fait orthodoxe. En particulier, il condamnait le recours au monachisme et professait la nécessité d'avoir un métier. En Égypte, c'est un chaykh d'Alexandrie, ibn 'Atallâh, (mort en 1309), farouche opposant à Ibn Taymiyya, qui fit connaître les « écrits » du maître, largement apocryphes. Cet ordre s'est répandu jusqu'en Asie du sud-est, connaissant également des subdivisions en une multitude de branches ${ }^{3}$.

8 La Khalwatiyya est, avec la Ahmadiyya et la Châdhiliyya, l'un des ordres soufis les plus répandus et les plus ramifiés de la vallée $\mathrm{du} \mathrm{Nil}{ }^{4}$. C'est le célèbre soufi persan Suhrawardî qui inspira cette importante confrérie orthodoxe fondée en Perse par 'Umar al-KhaIwatî (mort en 1397). Cet ordre, dont la discipline était très sévère (khalwatî signifie "retiré du monde »), se répandit en Turquie, au Caucase et en Azerbaïdjan, et c'est à la fin du Xve siècle qu'il fut introduit en Égypte et au MoyenOrient $^{5}$. Il faut noter que, à la fin du XVIII e siècle, c'est un disciple de la Khalwatiyya qui fonda la Tijâniyya en Afrique du nord-ouest. Cet ordre a toujours été en Égypte un ordre citadin, particulièrement lié aux grandes villes. II fut longtemps identifié comme l'ordre le plus turc de l'Égypte ottomane (les premiers Khalwatîs en Égypte furent trois Turcs d'Azerbaïdjan, Chams al-Dîn Damirdâch, Châhîn al-Khalwatî et Ibrâhîm Gulchânî, et de nombreux janissaires s'y retrouvèrent), ce qui ne l'empêcha pas de s'égyptianiser et de devenir l'une des plus influentes confréries du pays. Un chaykh de Damas, Mustafa Kamâl al-Dîn al-Bakrî, fonda, au milieu du XVIII ${ }^{\mathrm{e}}$ siècle, sa propre branche de la Khalwatiyya, la Bakriyya. Les chaykhs al-Bakri .domineront, avec une autre famille, les Sâdât, le monde soufi égyptien tout au long du XIXe siècle.

9 La Qâdiriyya est le plus ancien et le plus répandu, dans le monde, de tous les ordres soufis. Son fondateur, 'Abd al-Qâdir al-Gaylânî (mort en 1166), originaire de la Caspienne, s'était installé à Baghdad où il mourut et où se trouve aujourd'hui son tombeau. Le centre de la congrégation, à Baghdad, encore dirigé par un descendant direct du saint éponyme, rayonne dans toute l'Afrique du Nord, de là en Afrique noire, jusqu'en Indochine à l'est et en Turquie au nord. La Qâdiriyya est, de tous les ordres soufis, le plus pacifiste et humaniste. Il est opposé à tout fanatisme et extrémisme et répugne aux excès des ordres populaires les plus perméables aux pratiques religieuses non orthodoxes. Cet ordre, souple et adaptable, laisse une grande autonomie à ses nombreuses ramifications. A la fin du XIX siècle, Amadu Bamba a fondé au Sénégal un ordre typiquement africain, le Mouridisme, qui est une branche de la Qâdiriyya avec laquelle les liens sont seulement formels. En Égypte, une tradition fait de cette confrérie celle des pêcheurs.

10 Enfin, la Rifâ'iyya, fondée à Basra par un jeune contemporain de 'Abd al-Qâdir AlGaylâni, Ahmad al-Rifầ'i (mort en 1176), vient compléter le paysage du soufisme égyptien ${ }^{6}$. L'ordre s'est répandu en Égypte, en Turquie, et dans certaines régions de l'Asie du sud-est. La Rifâ'iyya devint une confrérie extrêmement populaire en Égypte médiévale, où Ahmad al-Rifâ'î fut considéré comme le saint patron des charmeurs de serpents. Le dhikr et le rituel de cet ordre ont pris des formes extravagantes. L'empreinte la plus visible laissée par la confrérie dans le paysage du Caire est la mosquée al-Rifâ'î, structure massive faisant face à la madrasa du sultan Hasan aux pieds de la citadelle, et qui fut construite à la fin du XIX siècle sur l'emplacement d'une zâwiya de la confrérie.

11 L'importance numérique de chacune de ces confréries a été très variable selon les époques. Toutefois, par son influence et le nombre élevé des loges qui se réclament de 
lui, c'est aujourd'hui l'ordre Ahmadiyya qui arrive en tête en Égypte, suivi de près par la Châdhiliyya et par la Khalwatiyya. Viennent ensuite la Burhâmiyya et la Rifâ'iyya. Il faut toutefois garder en mémoire que le corpus doctrinaire de chacun de ces grands ordres ne correspond plus, la plupart du temps, à la pratique des confréries nombreuses qui se réclament d'eux. En Égypte, pas moins qu'ailleurs, les déviations de la tradition mystique ont été la règle. Souvent, en l'absence d'une autorité centrale reconnue comme légitime, les modifications intervenues, souvent dues à des compromissions avec la religion populaire, donnent à une loge locale une identité tellement distincte qu'elle devient une confrérie en soi, dont le seul lien avec le nom qu'elle porte ne relève plus que de la généalogie spirituelle. De plus, la législation sur le soufisme a obligé de nombreuses confréries locales non reconnues à s'affilier à des grandes confréries officielles qui abritent ainsi des groupes tout à fait différents sans autre lien avec la tradition mystique dont ils ont adopté le nom, que ce nom lui-même. L'activité confrérique est centrée autour du personnage du fondateur de l'ordre et de son descendant, l'actuel chaykh. Les séances hebdomadaires de dhikr, les assemblées dans les mosquées, les tekkiyé et les zâwiya dépendant de la confrérie, sans oublier les visites aux tombeaux et les mawlid, commémorant la naissance d'un saint, sont les principales manifestations qui rythment la vie dévotionnelle des adeptes.

13 L'appartenance à une confrérie est avant tout un acte d'allégeance du disciple à son chaykh. L'autorité spirituelle absolue du chaykh soufi sur ses disciples est le principe de base de l'organisation soufie. Un guide vivant, même imparfait, est considéré comme absolument nécessaire. Le maître est souvent un homme instruit, parfois un uléma, mais il peut aussi quelquefois être un analphabète, c'est-à-dire un homme qui est incapable de lire lui-même les grands textes, mais qui compense cette infériorité, à la fois par l'intensité de sa vie spirituelle et une grande culture auditive. Le soufisme confrérique peut donc s'assimiler à un culte de la personnalité, avec toute la contradiction que cela implique avec les enseignements de l'islam orthodoxe qui interdit tout culte autre que celui rendu au Dieu unique. La raison de cette personnalisation semble être la crainte qu'en l'absence d'un guide, la confrérie s'atomise et que chaque disciple n'en vienne à suivre sa propre voie.

Il faut noter que la reconnaissance d'un chaykh est une attitude qui s'est renforcée au moment où l'islam sunnite a fermé la porte de l'ijtihâd. Dès lors, le maître a reçu l'initiation d'un autre maître qui lui-même tenait sa science et son charisme de son prédécesseur. Ainsi, des chaînes d'initiation font le plus souvent remonter à Hasan alBasrî et obligatoirement à 'Alî pour aboutir au Prophète, lequel fut initié par l'ange Gabriel. Ces généalogies d'autorités spirituelles, les silsila, probablement inspirées de l'institution des Isnâd pour authentifier les hadîth, sont là pour attester de la transmission du pouvoir spirituel. Chaque confrérie a sa chaîne d'initiation particulière. La plupart de ces généalogies sont pour la plupart fictives, mais elles montrent qu'à partir du XIII ${ }^{\mathrm{e}}$ siècle notamment, le soufisme sunnite a commencé à faire des imams chiites des autorités, afin de couper l'herbe sous le pied au chiisme. Aussi n'est-il pas étonnant que, de même que les chiites, le soufisme professe l'amour des gens de la famille du Prophète, de 'Alî et de ses successeurs. L'enseignement transmis par le maitre aux disciples est, aujourd'hui, beaucoup plus dévotionnel et moral que spéculatif : exercices pieux à accomplir d'une façon très précise, traditionnellement fixés dans la confrérie et porteurs de grâces, en plus des devoirs imposés à tout musulman. Un des exercices essentiels est le dhikr qui consiste à faire mémoire du nom 
de Dieu ou d'un certain nombre de ses noms, dans un ordre et selon un rythme de progression traditionnels et contrôlés, pour chaque disciple, par le chaykh. Répétition incessante du nom divin par la langue et par le coeur, le dhikr est accompli par chaque confrérie lors de séances à des dates fixes.

L'intercession des saints, membres de la famille du Prophète et fondateurs de confréries soufies, enterrés au Caire ou en province, joue un rôle central dans la culture soufie. La foi en les miracles (karâmât) fait partie du concept plus large du pouvoir spirituel des saints (awliyấ) transmis à leurs adeptes. Ce pouvoir spirituel est appelé baraka. Le chaykh actuel est le dépositaire de la baraka de ses prédécesseurs et plus particulièrement du fondateur de la confrérie. Le charisme des chaykhs donnait ainsi lieu à de spectaculaires manifestations qui ont frappé les voyageurs, véritable exhibitionnisme de "miracles» voulant attester les pouvoirs spirituels du saint fondateur. Nombreux sont les tombeaux et les reliques des saints et des saintes qui devinrent ainsi des objets de culte. Ces tombeaux et leur mosquée attenante sont visités par une foule continuelle et le lieu de pèlerinages annuels très fréquentés. Le culte des saints peut aller d'une simple piété, centrée sur la mosquée de la confrérie où est enterré le personnage source de charisme, aux pratiques les plus extravagantes. De nombreuses brochures à quelques piastres se vendent un peu partout avec les prières et formules dévotionnelles (awrâd) propres à la confrérie, des hagiographies et plus particulièrement toute une littérature à la louange du Prophète. Les récits abondent, soit sur leurs actes édifiants, soit sur les miracles qui se sont produits grâce à eux. Un certain nombre de pratiques en vue de la guérison, ou pour tout autre genre de protection, font ainsi partie des connaissances transmises de générations en générations.

Le culte des saints s'est répandu dès le $\mathrm{XI}^{\mathrm{e}}$ siècle. Ce n'est qu'avec circonspection que l'orthodoxie musulmane accepta le concept de sainteté (wilâya) ainsi que les miracles attribués aux prophètes et aux saints. Les ulémas n'ont pas cessé de discuter de la légitimité de ces conceptions et des pratiques qui y sont liées, mais la piété populaire a été la plus forte. La religion populaire, qui modifia radicalement le soufisme et son idéal, permit à une foule hiérarchisée d'intercesseurs de jouer un rôle que l'islam orthodoxe et le soufisme originel ne reconnaissaient pas.

A cela, il faut ajouter que l'extase personnelle à laquelle le soufisme peut conduire a également pu paraître condamnable dans la mesure où elle risquait de substituer l'inspiration subjective du mystique ou du saint aux données objectives de la révélation transmise par le Prophète, telles que le Coran et les hadîth les consignent. L'amour de Dieu pouvait s'avérer dangereux quand il n'était pas discipliné par le respect de la Loi telle qu'interprétée par les ulémas. Un hadîth soufi ne dit-il pas : «Dieu dit : Je suis ce que mon fidèle pense que je suis. » Aussi bien Ibn al-'Arabî que Jalâl ad-Dîn Rûmî ont insisté sur la relativité de la vérité religieuse. Le péril, aux yeux des ulémas, existe donc bien de voir la charîa, dont ils se veulent les gardiens, relativisée sous prétexte de soufisme. Les docteurs de la Loi se sont aussi souvent alarmés de la tendance du soufisme à déformer le système cultuel tel que le figh l'avait élaboré, en donnant la préférence, sur la prière rituelle, au dhikr, au concert spirituel (samâ'), voire même au chant et à la danse, la vie de retraite (khalwa) que préconisaient autrefois certains soufis est aussi parfois présentée comme incompatible avec les obligations sociales de la religion. On reproche au soufisme d'avoir introduit dans l'islam un idéal de vie monastique inspiré de l'exemple des chrétiens ; mais on admet cependant que cette vie 
puisse valoir la grâce divine si ceux qui la pratiquent ne cherchent pas à l'ériger en obligation universelle. Théologiens et docteurs de la Loi ont aussi critiqué l'esprit de confrérie favorisé par le soufisme et qui tendait à entretenir dans la communauté des divisions et un particularisme étranger à l'esprit de l'islam et contraire à l'unité prêchée par les ulémas. Mais l'idéal de la vie confrérique a exercé une telle attraction que d'aucun ont voulu voir dans la communauté musulmane, la tarîqa muhammadiyya, la confrérie de Muhammad.

Il n'est pas de notre propos de décrire ici les nombreuses croyances et pratiques que comporte l'islam dévotionnel des confréries soufies: au-delà de tous ses rites, des visites aux tombes des saints, avec attouchements et circumambulations, ou de la célébration des mawlid, le soufisme entend donner accès à tout un monde invisible. Ceci explique la facilité avec laquelle la mystique musulmane, en Égypte comme ailleurs, s'est compromise avec les croyances populaires locales. C'est en raison précisément de cette tendance au compromis que le soufisme s'avéra un vecteur aussi important pour la diffusion de l'islam. D'une façon générale, il n'est pas exagéré de dire que l'expansion actuelle de l'islam est redevable presque exclusivement à l'activité des confréries soufies. En Inde comme en Asie centrale ou en Afrique, le soufisme a amené des millions de conversions à l'islam, et, il est encore en Afrique un facteur important de prosélytisme. Le fait que le soufisme en vint à être assimilé à un instrument de conquête de l'islam sunnite a, cependant, grandement diminué son impact sur les chiites. Cette capacité des confréries soufies à susciter des conversions à l'islam constitue un argument de poids face aux plus critiques des ulémas.

Mais le système religieux des soufis a aussi été critiqué par les « réformistes » de toutes tendances, des libéraux laïcs aux fondamentalistes, qui l'assimilent à la pauvreté, à la passivité, à l'ignorance et, pour les fondamentalistes, à l'indulgence pour des pratiques de piété populaires plus proches de la superstition que de l'islam. Le soufisme leur paraît inadapté à une société moderne. Sa'ad Zaghlûl, comme beaucoup d'autres, y est allé de son couplet anti-soufi. L'émergence du mouvement réformiste musulman, à la fin du XIX ${ }^{\mathrm{e}}$ siècle, soucieux d'une compréhension littérale des textes sacrés et hostile à toute autre interprétation, a correspondu à la fin de l'indulgence des tenants de l'orthodoxie envers l'islam des confréries soufies. Après Al-Afghani et 'Abduh, Rachid Rida et les salafiyya ont critiqué le soufisme comme facteur d'arriération des sociétés musuhnanes. En 1904, la revue AL-Manâr émettait ce jugement sans appel : « Mais quel fut l'effet de l'influence croissante des chaykhs de confrérie sur les musulmans? D'une part, les objectifs du vrai soufisme ont été altérés et rien n'en subsiste aujourd'hui... excepté des bruits et des mouvements qu'ils appellent dhikr et que tout véritable soufi ne pourrait que condamner; il y a, de plus, la glorification religieuse des tombes des chaykhs avec la croyance qu'ils possèdent des pouvoirs cachés... et ceci est contraire au Livre de Dieu et à la sunna du Prophète ${ }^{7} »$. Au lieu, disent les adversaires du soufisme contemporain, d'être une méthode d'autodiscipline morale, d'élévation et d'illumination purement spirituelles, le soufisme, la démagogie des chaykhs soufis aidant, a ouvert le voie à toutes les aberrations et à tous les charlatanismes, avec pratiques hypnotiques, visions, transes perpétuelles et délires théosophiques. Et certains d'ajouter: "Mendiants et parasites se sont proclamés chaykhs de nouvelles confréries, mettant ainsi l'islam à la merci de délinquants ${ }^{8}$.» A de telles critiques, il était difficile aux confréries de répondre, n'ayant aucun leader capable de réfuter les arguments anti-soufis. Bien que légitime, le dhikr a été attaqué par certains ulémas et certaines organisations « orthodoxes » créées dans les années 20, comme les Ansâr al- 
Sunna al-Muhammadiyya (les Partisans de la sunna muhammadienne). Toutefois, le prestige de l'idéal soufi demeurait: Hasan al-Banna ne décrit-il pas les Frères musulmans comme un « mouvement salafiste, une réalité soufie ».

Basées sur le pouvoir charismatique d'un saint et de son descendant, les confréries soufies croient en une réalité qui est supérieure à la réalité matérielle. La relation personnelle du chaykh et du murîd, son adepte, incorpore ce dernier à un monde caché où la force de ses émotions et la pureté de son amour lui permettent une fusion avec l'être divin. Cette relation verticale privilégiée et irrationnelle entre Dieu et sa créature est exclusive. Rejetant certains, des principaux attributs de ce qui fait l'Égypte moderne, comme l'intérêt pour la politique, les adeptes des confréries n'en sont pas moins en prise directe avec un autre niveau de conscience. C'est dans le coeur de chaque croyant, plus que dans la société, qu'il convient de le situer.

L'institutionnalisation de la mystique organisée

21 Cet énorme potentiel que représente la mystique organisée en Égypte a été l'objet de tentatives continues de contrôle par le pouvoir politique. Le moyen en a été la mise en place d'une législation toujours plus contraignante. Les différentes étapes de cette domestication du soufisme par l'État sont exemplaires à bien des égards, ne serait-ce que parce qu'elles illustrent la formation d'un certain système politique.

Ce fut d'abord la rencontre de la volonté politique du pouvoir à l'égard des confréries soufies avec l'émergence de familles qui allaient être l'instrument privilégié des initiatives successives de l'État en vue d'institutionnaliser la mystique. En ce qui concerne ces familles, il faut rappeler que la fonction de naqî̉ al-achrâf dépendait, jusqu'au XviI ${ }^{e}$ siècle, d'Istanbul, mais qu'à partir de là, le naqî́b devait obligatoirement appartenir soit à la famille al-Bakrî, qui patronnait l'ordre soufi de la Bakriyya, soit à la famille al-Sâdât, à la tête d'un autre ordre, la Wafâ'iyya. Les chaykhs al-Bakrî et alSâdât se répartirent de même successivement la fonction de chaykh machâyikh al-turuq al-sûfiyya, c'est-à-dire de chef suprême des confréries soufies. Non seulement ils dirigeaient leur propre confrérie, mais ils nommaient les chaykhs des autres confréries, dirigeaient leurs cérémonies et exerçaient une grande influence dans le choix du Chaykh AL-Azhar. Ces deux positions, naqîb et chef suprême des confréries soufies, permirent à ces deux familles aristocratiques de former une élite héréditaire alors que leurs ordres n'étaient ni les plus importants ni les plus populaires. Les chaykhs al-Bakri et al-Sâdât, qui avaient le titre de chaykh al-siggâda, étalent les deux ulémas les plus riches et les plus puissants d'Égypte. Le mawlid du Prophète, la plus importante des fêtes religieuses du Caire, était célébré par chaykh al-Bakri. Le mawlid de Husayn, le second en importance après celui du Prophète, était célébré par chaykh al-Sâdât. Ces événements s'accompagnaient de la présence du wali, du gouverneur ottoman et des beys mamelouks. Ces deux familles allaient dominer le monde soufi tout au long du XVIII ${ }^{e}$ siècle, avant que la famille al-Bakri ne monopolise ensuite à son seul profit les fonctions jusqu'alors partagées avec les Sâdât.

L'histoire ottomane offre une belle illustration des efforts de contrôle des confréries soufies par l'État, L'institution d'un chaykh al-turuq, chaykh des confréries, dans les grandes villes correspondait au souci manifesté par la Porte de centraliser le soufisme. L'itinéraire de la Bektachiyya est à cet égard exemplaire. Sous le règne de 'Abdûlhamit, les chaykhs de confrérie soufis, promus par le sultan-calife à des postes honorifiques, constituèrent la base de sa politique religieuse, comme l'illustre l'activité de chaykh Muhammad Abû'-l-Hûda al-Sayyâdi, le chef de la Rifâ'iyya, qui joua le rôle de commis 
voyageur du panislamisme dans les provinces arabes de l'Empire. Muhammad 'Ali semble bien avoir retenu la leçon lorsqu'il investit chaykh al-Bakrî d'une autorité suprême sur les ordres soufis d'Égypte.

Selon une idée très répandue en Égypte, c'est Saladin qui institua la fonction de chaykh machâyikh al-turuq al-sûfiyya. Chaykh Abû-l-Wafa Taftâzânî, l'actuel chaykh suprême des confréries soufies, soutient lui-même cette idée, niant qu'il puisse s'agir d'une institution moderne. En fait, sa systématisation date du XIX siècle, plus précisément du règne de Muhammad 'Alî. C'est là, vers 1802, qu'il faut situer le début de l'institutionnalisation d'une autorité centrale sur les confréries soufies. En voici les principales étapes ${ }^{9}$ :

- 1812 : Muhammad 'Alî promulgue un firman attribuant à chaykh al-Bakri une autorité exclusive sur le monde soufi (confréries et institutions dépendant des confréries comme les tekkiyé, les zâwiya et les tombeaux). Jamais auparavant, les confréries soufies n'avaient été soumises à une autorité centrale. Le principe de qadam (prérogatives dues à l'ancienneté) oblige la plupart des confréries à se mettre sous l'autorité d'al-Bakrî pour survivre. Le soufisme devint une discipline enseignée à Al-Azhar, tandis que Muhammad 'Ali utilisait la puissance des confréries dans le bras de fer qu il avait engagé contre les ulémas. Ce cas de figure, l'opposition entre les ulémas d'Al-Azhar, citadelle de l'orthodoxie, et le mysticisme populaire favorisé par le pouvoir, sera désormais familier à l'Égypte.

- 1847 : un premier accord délimite les compétences du Chaykh d'Al-Azhar et celle de Muhammad al-Bakri. Al-Azhar se voit retirer tout pouvoir sur le monde soufi, c'est-à-dire sur un aspect majeur de l'islam égyptien. A partir de ce moment, il apparaît que chaykh alBakri est la seule autorité que trouvent en face d'elles les confréries soufies. C'est par l'intermédiaire de chaykh al-Bakrî que les chaykhs des confréries reçoivent du gouvernement des émoluments qui leur permettent de financer les activités de leur ordre.

- 1848 ; une première liste officielle des confréries soufies est publiée sous le contrôle de chaykh al-Bakrî. Ce dernier est donc désormais l'autorité qui donne le droit de pratiquer la mystique en Égypte.

- 1859 : un décret khédivial place les chaykhs des tombeaux, des mausolées et des tekkiyé sous la juridiction de chaykh al-Bakrî.

- 1872 : afin de consolider l'autorité de chaykh al-Bakrî sur les confréries, les séances de dhikr dans les maisons privées sont interdites. Tous les représentants des chaykhs soufis, les khalifa et les nâ'ib, passent sous le contrôle de chaykh al-Bakrî.

- 1881 : sous la pression du khédive Tawfîq, chaykh al-Bakrî entreprend plusieurs réformes concernant la restriction de certaines pratiques rituelles jugées incompatibles avec l'orthodoxie, de même qu'il intervient de plus en plus dans les affaires intérieures des confréries, menaçant l'autonomie des chaykhs. La fameuse dawsa, cérémonie au cours de laquelle les chaykhs de la Sa'adiyya passaient à cheval sur le corps de leurs adeptes étendus à plat ventre sur le sol, fut ainsi interdite. Jusqu'alors, la structuration du monde soufi sous la houlette de l'État et l'ascension des chaykhs al-Bakrî avait correspondu aux intérêts des chaykhs soufis. Avec la nouvelle circulaire de 1881, qui donne à chaykh al-Bakrî un pouvoir de contrôle sur le fonctionnement interne de chaque confrérie, cette conjonction d'intérêts se rompt. En faisant acte d'autorité envers les plus grandes confréries, chaykh al-Bakrî risquait de perdre sa légitimité aux yeux du monde soufi. Il s'ensuivit une multiplication des confréries soufies, à cause de nombreuses scissions, et une prolifération des confréries non reconnues, illustrant la volonté d'échapper au contrôle conjugué du pouvoir et de chaykh alBakrî. Telle sera, à l'avenir, la réponse du soufisme confrérique lorsque le contrôle de l'État se fera trop pesant. 
- 1892 : chaykh Muhammad Tawfîq al-Bakri est le premier à prendre officiellement la tête de la machyakha (assemblée des chaykhs) des confréries soufies. Il publie une liste des confréries officielles, les autres se voyant interdire toute activité, notamment celles n'ayant pas de chaykh résidant au Caire et dont le contrôle s'avérait plus difficile.

- 1895 : par un décret khédivial, un « règlement des confréries soufies » abroge toutes les dispositions de 1881. Selon le nouveau règlement, la fonction de chaykh machâyikh al-turuq alsûfiyya n'est plus obligatoirement attachée à celle de chaykh de la confrérie Bakriyya. Elle devient une véritable fonction officielle sans lien héréditaire. La position de chaykh al-Bakrî en tant que chef suprême des confréries soufies se transforme d'une autorité traditionnelle en un pouvoir légal. Toutefois, les chaykhs al-Bakrî continueront à occuper la fonction jusqu'en 1947. Avant 1895, la direction des confréries soufies ne possédait pas d'organisation administrative connue. Pour la première fois, un Conseil soufi est institué, présidé par alBakrî, rassemblant vingt chaykhs de confrérie élus au siège du gouvernorat du Caire pour trois ans. Dirigé par quatre chaykhs élus par leurs pairs, avec le chaykh machâyikh comme président, ce Conseil devient l'autorité suprême sur le monde soufi, avec le pouvoir de reconnaître officiellement les confréries et de nommer leur chaykh. Dotées d'une direction officielle collective, les confréries retrouvent ainsi une certaine autonomie interne, dont la diminution avait mis à mal l'autorité d'al-Bakrî. Les institutions dépendant des confréries passent sous la juridiction du ministère des Waqf et non plus sous celte de chaykh al-Bakri.

- 1903 : le « Règlement des confrérie soufies », proclamé par décret khédivial le 3 juin, vient amender le décret de 1895. Le Conseil soufi ne se limite plus aux chaykhs des confréries résidant au Caire, mais étend son champ d'action à tous ceux d'Égypte. Les confréries non reconnues sont forcées de se rattacher officiellement à des confréries reconnues. La machyakha 'âmma, représentant l'ensemble des chaykhs des confréries soufies, fait obligation à ces derniers d'avoir une hiérarchie de représentants (khalîfa, nâ'ib, wakîl et autres représentants) dûment mandatés et responsables devant eux ${ }^{10}$.

- 1905 : promulgué par le Conseil soufi, le 22 avril 1905, un « Règlement interne des confréries soufies ", complément du précédent, achève le processus d'institutionnalisation de la mystique. Le contrôle du khédive sur le Conseil est renforcé, les chaykhs de confrérie se voient obligés de répondre à certaines obligations qui les intègrent encore davantage à l'administration de l'État. Ainsi, les séances publiques de dhikr sont désormais assimilées à des rassemblements illégaux si elles sont tenues sans la présence d'un khalîfa en possession d'une igâza, un permis du chaykh, Les confréries non reconnues doivent s'affilier à des ordres officiels pour avoir le droit de participer aux manifestations données lors des fêtes religieuses. Les nouvelles prérogatives du Conseil soufi rendent caduc le principe de qadam, qui est aboli. Cependant, malgré l'opposition des chaykhs, la législation de 1905 laisse à chaykh al-Bakrî un pouvoir énorme sur les confréries ainsi que sur les institutions qui en dépendent. Les décrets de 1903 et de 1905 faisaient de la fonction de chef suprême des confréries soufies une autorité sans précédent sur le monde soufi. Ces dispositions demeureront en vigueur jusqu'en $1976^{11}$.

- 1911 : Muhammad Tawfîq al-Bakrî perd ses titres de chaykh al-saggâda al-Bakriyya et de naqîb al-achrâf. C'est le début d'un lent déclin de la position des chaykhs al-Bakrî,

- 1946 : le dernier chaykh al-Bakrî, Ahmad Murâd al-Bakri, est relevé de ses fonctions de chef suprême des confréries soufies par le roi Fârûq, à cause de son soutien au mouvement antiégyptien au Soudan. Son successeur, chaykh Ahmad al-Sâwî, siégera à la tête des confréries soufies jusqu'en 1958. Pour la première fois, la fonction échappait au chaykh de la Bakriyya. La famille al-Bakrî se voyait écartée après avoir permis à l'État d'asseoir son contrôle sur les confréries. 
- 1952 : à partir de la révolution, des projets successifs vont tendre à réformer et à réglementer le soufisme en remplacement des règlements de 1903 et de 1905. L'abolition des waqf ahliyya crée d'importantes difficultés financières pour les chaykhs.

- 1955 : ce n'est qu'en mars 1955 que le gouvernement militaire commence véritablement à s'intéresser aux confréries soufies. 'Abd al-Hakîm 'Amir est chargé de superviser les efforts visant à la réforme des confréries. Cet intérêt soudain semble être lié à l'interdiction prononcée contre les Frères musulmans en 1954. L'intervention systématique du pouvoir dans les affaires des confréries suscite, de nouveau, une prolifération de confréries schismatiques qui refusent de servir d'instrument politique. Le nombre des confréries sans statut officiel prend de l'importance, qu'il s'agisse de confréries locales ou de confréries supranationales.

- 1958 : le Conseil de la Révolution promulgue un « guide pour les soufis » qui fait du Conseil soufi le représentant de tous les ordres, officiels ou non. Sayyid Muhammad Mahmûd 'llwân, chaykh de la confrérie Ilwâniyya, devient le chaykh suprême des confréries soufies en 1958, fonction qu'il occupera durant toute l'ère nassérienne, jusqu'en 1970. Il agira comme le véritable porte-parole de la politique nassérienne envers les confréries soufies. Sous son impulsion, un comité de réforme du soufisme verra le jour, répondant aux voeux du régime nassérien. En septembre 1959, chaykh Muhammad Mahmûd 'Ilwân fait un discours où il dit son désir de réorganiser les soixante confréries officielles sur une base compatible avec les objectifs du socialisme arabe ${ }^{12}$. Une réunion a lieu au siège de l'Union socialiste arabe pour discuter de cette réorganisation sous le patronage du régime socialiste, mais elle, n'a pas d'effets concrets. Les tentatives de réorganisation des confréries soufies ne se réaliseront que sous Sadate.

- 1970 : succédant à chaykh Muhammad Mahmûd 'llwân, décédé cette année-là, chaykh Muhammad Mahmûd al-Sutûhî occupera la fonction de chaykh suprême des confréries soufies tout au long du règne de Sadate, jusqu'à sa mort en décembre 1982. Le nom de chaykh Sutûhî demeure attaché au renouvellement complet de l'arsenal législatif concernant le soufisme. Sous son mandat, on promulgue la loi 118 de 1976 et le décret de 1978, qui régissent jusqu'à nos jours la mystique organisée en Égypte.

- 1976 : le « Règlement intérieur des confréries soufies », promulgué le 9 septembre, met un terme à 75 ans de validité de l'ancien régime basé sur les lois de 1903 et de 1905. La loi 118 de l'année 1976 abroge toutes les législations antérieures jugées comme « ayant fait leur temps » et « en désaccord avec le réveil moderne ${ }^{13}$ ». La nouvelle législation augmente de façon spectaculaire le pouvoir $\mathrm{du}$ «Conseil supérieur des confréries soufies ». Cette institution cumule désormais les pouvoirs législatifs, judiciaires et exécutifs dans le domaine de la mystique organisée. Elle est investie du droit exclusif d'approbation de toute activité mystique publique ou privée, ainsi que du droit de contrôle et de supervision du soufisme. Le Conseil supérieur dispose de moyens légaux pour exercer ce droit. En même temps que son pouvoir augmente, il voit le nombre de ses membres passer de cinq à onze, dont cinq membres extérieurs représentant Al-Azhar et divers ministères. Tous les ordres soufis non reconnus sont déclarés illégaux, ce qui oblige les nombreuses confréries sans statut à se réfugier sous la protection d'une confrérie officielle.

- 1978 : par décret présidentiel ( $\left.n^{\circ} 54\right)$ daté du 30 janvier, le « Règlement exécutif des confréries soufies » vient compléter la loi 118 de 1976. L'un des premiers articles du règlement de 1978 stipule : «Ce Conseil (le Conseil supérieur des confréries soufies) est un organisme doté d'une personnalité morale indépendante, dont les objectifs sont religieux, spirituels, sociaux, culturels et patriotiques, et qui se trouve lié dans toutes ses activités par les enseignements du Livre de Dieu et la sunna du Prophète ${ }^{14}$. " 
de 1976 et le règlement de 1978 illustrent l'aboutissement des efforts de l'État égyptien, depuis les premières années du régime nassérien, pour intégrer les confréries dans une structure légale dotée d'un pouvoir étendu afin de les contrôler plus efficacement. Les confréries se sont vues assigner des objectifs sociaux et patriotiques qui ne répondent pas précisément à leur raison d'être. Toutes ces transformations, avec l'augmentation de l'autorité du Conseil supérieur des confréries soufies, ont gravement entamé l'indépendance des chaykhs soufis. Aujourd'hui, c'est le Conseil supérieur des confréries soufies qui nomme les chaykhs des confréries. Le Conseil ratifie également le choix des représentants des chaykhs à tous les échelons de la hiérarchie confrérique : depuis le khalîfa, au niveau des zâwiya, jusqu'au wakîl, en passant par le khalîfa alkhulafâ' et le nầib, ainsi que les responsables des tombeaux et mausolées dépendant des confréries, tous doivent recevoir une approbation officielle. L'assemblée générale des chaykhs de confréries soufies (machyakha 'âmma), dont le Conseil est l'émanation, dispose d'un corps de représentants propre, les wakîl, qui contrôlent l'exécution de ses décisions. l'obligation qui leur est faite de se former à Al-Azhar à l'école d'une certaine orthodoxie. Comme pour mieux marquer son institutionnalisation, la création d'un institut du soufisme fut même prévue. Le résultat a été d'amener à la tête des confréries de nombreux chaykhs ingénieurs, docteurs es lettres, avocats, hautfonctionnaires de formation azharienne. Transformé en administrateur davantage qu'en chef spirituel, le chaykh soufi se voit soumis à une forme rampante de sécularisation. Dès lors, la personnalité du khalîfa local revêt toute son importance en tant que principal récepteur d'un charisme que le chaykh a de plus en plus de mal à exprimer. De même, une certaine opposition entre laïcs et mystiques au sein des confréries s'exprime de temps à autre.

Aux termes de la loi 118 de 1976 et du décret de 1976, le Conseil supérieur des confréries soufies est élu par l'assemblée générale des chaykhs des confréries soufies au siège du gouvernorat du Caire à 'Abdîn pour trois années. Le Conseil est aujourd'hui composé de quinze membres, dont le chaykh suprême des confréries soufies qui doit être choisi parmi les chaykhs soufis déjà membres du Conseil supérieur, ainsi que de dix chaykhs de confrérie élus à bulletin secret, d'un représentant d'Al-Azhar, choisi par le Chaykh Al-Azhar, de trois représentants respectivement du ministère des Waqf, du ministère de l'Intérieur et du ministère de la Culture, choisis par les ministres, ainsi que d'un représentant de l'autorité locale, en l'occurrence le gouvernorat du Caire. Le choix du chaykh suprême des confréries soufies doit être entériné par le président de la République. Doté de tous les attributs du pouvoir sur la mystique organisée, le Conseil se voit contraint de tenir un budget auquel participent les caisses d'offrandes, tandis que ses finances sont déclarées publiques. Symbole de ce nouveau visage que le pouvoir et les chaykhs veulent donner du soufisme, le Conseil supérieur des confréries soufies s'installe en 1978 à son nouveau siège, place Husayn, lieu traditionnel des manifestations religieuses populaires et officielles. Les lois de 1976 et 1978 systématisent, d'autre part, une politique de publication de revues et journaux, tandis que la diffusion des awrâd (les prières rituelles) de chaque confrérie est soumise au contrôle du Conseil.

En mai 1979, une nouvelle revue mensuelle, Tasawwuf islâmi (Le soufisme islamique), porte-parole de l'assemblée générale des chaykhs des confréries soufies, illustre les 
nouvelles orientations imprimées au soufisme. Dans son premier numéro, la revue publie une interview de Sadate : "Ne jugez pas le soufisme sur les actes répréhensibles des déviationnistes. Le soufisme a un besoin urgent d'un important effort sur lui-même. Il doit être purifié des innovations et des superstitions, il faut répandre l'héritage du véritable soufisme, et condamner sans appel les joueurs de percussions et les mangeurs de serpents " (allusion aux pratiques de certaines confréries jugées non conformes à l'islam). Tasawwuf Islami vient en remplacement de l'ancienne revue du Conseil soufi, Magalat al-isIâm wa-l-Tasawwuf (Revue de l'islam et du soufisme). Publiée de 1958 à 1962, celle-ci s'adressait plus spécialement aux membres des confréries. La revue Tasawwuf IsIâmî, distribuée dans les kiosques à journaux, est adressée à un public plus large. Avec un tirage de vingt mille exemplaires, ce périodique auquel tous les khaliffa de confrérie sont obligatoirement abonnés est probablement l'un des .périodiques religieux qui a la plus grande audience en Égypte.

29 L'Égypte est ainsi le seul pays arabe où l'existence d'ordres mystiques ait une base légale très précise. L'existence de telles lois est en soi un phénomène caractéristique d'un certain système politique. Médiateur entre Dieu et son adepte, le chaykh soufi l'est maintenant également devenu entre l'État et ce même adepte, grâce à un système de métaphores comprises à différents niveaux. Le charisme du chaykh, qui est le véritable objet de l'adhésion à une confrérie, est utilisé comme le vecteur d'un islam réformé dont l'État se veut le défenseur. Comment ne pas reconnaître là un certain système politique directement inspiré de celui des Ottomans? De même que le sultan-calife avait institué différentes fonctions visant à intégrer à l'État ottoman les chaykhs des confréries soufies, l'État égyptien a systématisé sa mainmise sur la mystique organisée par un code de lois très coercitif. De même que les chaykhs soufis s'étaient, sous Abdulhamit, fait les propagandistes du panislamisme alors prôné par le pouvoir, les chaykhs soufis égyptiens entendent, aujourd'hui, défendre l'islam tel que le conçoit l'État.

En effet, le réformisme musulman a bouleversé les données. Une nouvelle lecture du Coran, attachée au respect de la lettre des textes sacrés, s'est imposée comme l'idéologie islamique dominante, dont les confréries soufies ont été la cible privilégiée. Soumis à la pression des fondamentalistes et lui-même partisan de ce qu'il perçoit comme une manifestation de la modernité dont il se veut le principal vecteur, l'État se fait le relais - et les médias avec lui - de cette idéologie. Un fondamentalisme d'État s'est substitué à l'indulgence de la période pré-réformiste pour les pratiques soufies les plus extravagantes. Dès lors, l'objectif du pouvoir est de mener de front intégration et réforme des confréries soufies, d'où les invitations, devenues rituelles, à la purification du soufisme, à la lutte contre les superstitions et au respect de la lettre du Coran et de la sunna.

31 Pour mieux illustrer ce soufisme réformé que le pouvoir appelle de ses voeux, la revue Tasawwuf Islami publie de nombreuses interviews de personnalités religieuses extérieures au soufisme, comme pour mieux donner à celui-ci un brevet de conformité avec la charîa. Le prédicateur Muhammad Mitwalli al-Cha'râwî, le Chaykh Al-Azhar actuel, Gâd al-Haqq, ainsi que des représentants d'Al-Azhar, le mufti de la République, les représentants du ministère des Waqf, font partie de ceux qu'on retrouvent habituellement sollicités pour des articles ou des entretiens. Jusqu'à 'Umar Tilmisânî, le chef des Frères musulmans sortant de prison, qui se verra lui aussi ouvrir les colonnes de la revue soufie. L'enjeu, pour l'État, est de canaliser à son profit la formidable 
aspiration au surnaturel qui continue à caractériser la société égyptienne, et de lui donner un visage "présentable" au regard des nouveaux critères islamiques de la modernité. En associant officiellement le ministère des Waqf et Al-Azhar aux efforts de réforme du soufisme, le pouvoir incorpore non seulement sous son aile toutes les institutions islamiques, mais il donne ainsi une caution d'orthodoxie au Conseil supérieur des confréries soufies. La séparation des sphères d'Al-Azhar et du soufisme au $\mathrm{xIX}^{\mathrm{e}}$ siècle aboutit au retour d'un contrôle, au moins moral, de l'institution musulmane sunnite millénaire sur les confréries.

L'islam soufi, un islam populaire et prépondérant

Solidement ancré dans la réalité sociale, nous rappelle encore Gilbert Delanoue, le soufisme confrérique, au $\mathrm{xIX}^{\mathrm{e}}$ siècle, se développait tout seul, sans intervention officielle autre que des dons de riches et puissants personnages. Après plus d'un siècle marqué par un processus d'institutionnalisation croissante, qu'en est-il de l'impact des confréries soufies? L'intervention continue de l'État, porte-parole d'une idéologie islamique moderne, a-t-elle porté atteinte à cette manifestation majeure de la religion en Égypte ? Précisons d'abord qu'il n'y a pas aujourd'hui de pays au Moyen-Orient où les confréries soufies soient aussi prédominantes, aussi nombreuses et aussi répandues qu'en Égypte. Il suffit de rappeler que, d'après une estimation semi-officielle récente, le nombre d'adhérents à des confréries soufies s'élève à six millions ${ }^{15}$, organisés en plus de cent vingt confréries. C'est-à-dire qu'une proportion importante de la population masculine égyptienne est, d'une manière ou d'une autre, engagée dans les confréries mystiques (les femmes n'ayant pas accès aux confréries). Si l'on considère que ces adeptes influencent directement leur entourage, depuis la famille jusqu'au milieu professionnel en passant par l'armée, on constate que le soufisme, en Égypte, n'est en rien une force marginale au sein de la société.

L'éthique propre au soufisme, le caractère populaire des confréries, certaines pratiques difficilement compatibles avec le renouveau d'orthodoxie prôné par les réformistes, une méfiance pour l'attitude politique de l'une ou de l'autre confrérie, ont fait sousestimer l'importance des confréries soufies. Nombreux ont été les intellectuels égyptiens qui exprimaient une certaine répugnance face à un phénomène jugé rétrograde. Quelques cérémonies, marquées par des rites violents, existaient encore au temps de Lane, cet observateur anglais qui les a décrites dans son ouvrage sur les coutumes en Égypte au $\mathrm{XIX}^{\mathrm{e}}$ siècle ${ }^{16}$. Depuis lors, les pratiques les plus décriées ont disparu. Les séances de dhikr ont lieu à des dates régulières. Ce sera fréquemment dans la soirée qui précède le vendredi ou le vendredi même. Elles peuvent se dérouler, sous la direction d'un khalîfa, dans une mosquée dépendant du ministère des Waqf, après accord de l'imam de la mosquée, dans la mosquée propre à la confrérie ou dans une zâwiya, dont le nombre auiourd'hui en Égypte se chiffre par centaines.

Le réseau des zâwiya n'a actuellement aucun équivalent par son étendue et ses ramifications. Unité de base du soufisme, la zâwiya est souvent directement rattachée à un tombeau. Aucune ville, aucun village, aucun quartier qui ne soit structuré autour de ce lieu privilégié de la socialisation soufie. Durant le mois de ramadan, les confréries pratiquent le dhikr dans les tentes de cérémonies tendues le long de la mosquée de Husayn, selon un ordre établi par le Conseil supérieur des confréries soufies. Toutefois, le dhikr n'est pas toujours contrôlé et, notamment lors des mawlid, il continue souvent à se pratiquer selon des modes jugés répréhensibles: mixité, musique, percussions et danses sont alors courantes. En plus du dhikr, des hadra, réunions mystiques, ont lieu 
chaque semaine dans les mosquées et au siège de chaque confrérie, rassemblant un public très variable selon les confréries.

Mais ce sont surtout les grandes fêtes musulmanes et les commémorations annuelles des saints, occasion de grands rassemblements, au Caire ou en province, qui permettent le mieux de mesurer l'impact extraordinaire des confréries soufies. Le culte des saints, les visites aux tombeaux et les mawlid peuvent être considérés comme l'une des expressions les plus authentiques de la piété populaire égyptienne. Le nombre des mawlid en Égypte échappe à toute évaluation précise, mais il est imposant D'après les communiqués du ministère des Waqf, il y a chaque année plus de quarante commémorations de la naissance de saints, membres de la famille du Prophète et soufis célèbres pour la plupart. A cela, il faut ajouter, d'après le Conseil supérieur soufi, au moins quatre-vingt mawlid de saints fondateurs de confrérie. On arrive donc au chiffre minimum de 120 mawlid par an en Égypte, c'est-à-dire de dix mawlid chaque mois. Mais, d'après Akhbâr al-Yawm, le nombre annuel des mawlid célébrés en Égypte doit être estimé à trois mille ${ }^{17}$. Ce chiffre est certainement exagéré à dessein. Régulièrement dénoncés, les méfaits des mawlid, que leurs adversaires estiment sans utilité sociale, sont ainsi mis en exergue. De plus, leur nombre et leur ampleur sont souvent jugés comme autant de réminiscences de cultes païens rendus aux morts. Mais ces chiffres n'en sont pas moins révélateurs. La tendance est à la multiplication des lieux de pèlerinage autour des tombes, non seulement des chaykhs fondateurs de confréries, mais aussi de leurs successeurs et même des tombes des véritables dynasties de gardiens de tombeaux. L'assistance lors de ces festivités est très variable : certains mawlid, commémorant la naissance du fondateur d'une simple confrérie ou un saint local, peuvent n'attirer guère plus que quelques centaines de personnes. Mais ce sont des foules immenses qui se rassemblent lors des grandes commémorations d'un saint considéré comme patrimoine commun de toutes les confréries soufies,

Les lieux de pèlerinage sont entourés de l'auréole du Prophète. Les saints personnages ont vulgarisé des prières dans lesquelles est certes exaltée la grandeur de Dieu l'unique, mais où apparaît également une ferveur spéciale pour le fondateur de l'Islam. C'est pourquoi, dans les généalogies mystiques d'initiation, la liste des initiateurs remontent toujours jusqu'à Muhammad et l'archange Gabriel. Aussi ne s'étonnera-t-on pas du nombre des tombeaux et des pèlerinages consacrés à des descendants du Prophète. Pour la seule ville du Caire et de sa banlieue immédiate, on dénombre douze mosquées dédiées à des descendants du Prophète, deux à des grands docteurs de la Loi, et quinze à des soufis célèbres.

Dans la hiérarchie de la sainteté, les gens de la famille du Prophète possédant un tombeau au Caire sont considérés comme ceux dont la baraka est la plus influente ${ }^{18}$. A cet égard, la tombe qui renferme la tête de Husayn, le petit-fils du Prophète, est certainement le sanctuaire qui est affectivement le plus important pour les Égyptiens et la mosquée qui la renferme le lieu le plus visité. C'est la mosquée de Husayn, et non AlAzhar, qui constitue le véritable centre sacré du Caire, le point de ralliement de toutes les cérémonies religieuses. Viennent ensuite la tombe de Zaynab, fille de Fâtima et de 'Alî et soeur de Husayn, et enfin celle de Nafîsa, arrière-petite-fille de Hasan. Protecteur du quartier de Gamâliyya, Husayn demeure une figure unanimement affectionnée (il suffit de lire les romans de Nagîb Mahfûz pour s'en persuader), tandis que Zaynab et Nafîsa sont, avec Ruqayya, une autre fille de 'Alî, considérées comme les saintes patronnes de la ville du Caire. Comme pour une bonne partie des tombeaux musulmans 
en Égypte, ceux-ci sont certainement « apocryphes ». De nombreuses traditions situent la tête de Husayn ailleurs, à la mosquée des Omeyyades de Damas, à Alep, à Raqqa ou à Achkelon, sans compter les chiites pour lesquels la tête est enterrée avec le corps à Karbalâ'. Zaynab ne serait jamais venue en Égypte et Ruqayya est enterrée à Damas. Ce qui compte, en l'occurence, est le symbole, et ces personnages n'en dominent pas moins le "panthéon" cairote des saints musulmans. La tombe de Husayn est plus particulièrement visitée le mardi par les hommes et le samedi par les femmes; celle de sayyida Zaynab le mercredi, par les femmes. Comme la mosquée de Husayn, celle de Zaynab est l'objet de la sollicitude de la riche communauté ismaélienne, dirigée par l'Aghâ Khan, et connue en Égypte sous le nom de Bahra. Le chef de la communauté Bahra, essentiellement indo-pakistanaise, sayyid Muhammad Burhân ad-Dîn Bahra, a entrepris de restaurer et d'embellir, outre les monuments fatimides, ceux attachés aux membres de la famille du Prophète. Ces tombeaux bénéficient ainsi, pour le plus grand plaisir des pèlerins, d'une attention que les seules ressources de l'État ou les donations ne permettraient pas.

38 L'imam Châfiî, dont la tombe, dans la Cité des Morts qui porte son nom, est la plus vénérée après celle de Nafîsa, reçoit une foule importante de pèlerins le vendredi, avant la prière de midi. Le fondateur du rite chafi'ite, l'un des quatre grands rites sunnites auquel adhèrent la grande majorité des Égyptiens, demeure à la fois une autorité légale pour les ulémas et un saint pour les petites gens. La tombe de l'imam alLayth, un disciple de Châfi'i lui aussi révèré comme un saint, se trouve à proximité. Sayyida Sakîna (on prononce parfois Sukayna), une fille de Husayn, occupe une place tout juste inférieure à celle de l'imam Châfi'î dans la piété populaire. Vient ensuite le frère de Sayyida Sakîna, 'Alî Zayn aI-'Abidîn, fils de Husayn que les chiites reconnaissent pour leur quatrième Imam, et qui a, selon une tradition sunnite, sa tête enterrée dans un quartier nord de la Cité des Morts qui porte son nom: Hasan alAnwar, le père de Nafîsa, Fâtima Nabawiyya, une autre fille de Husayn, dont le tombeau se situe dans le quartier populaire de Darb al-Ahmar, et sayyida 'Aicha, une fille de Ga'far al-Sâdiq, le sixième Imam des chiites, complètent la liste des gens de la famille du Prophète jouissant d'une vénération particulière.

L'importance du rôle d'intercesseur attribué aux saints a été illustrée par l'affaire des lettres adressées de toute l'Égypte au tombeau de l'imam Châfi'i dans les années 1960. Intriguée par cet afflux de courrier, l'administration des postes égyptiennes décida de prendre connaissance de leur contenu. La plupart faisaient des demandes d'intercession (madad) pour des problèmes de vie quotidienne, d'autres formulaient des plaintes et certaines dénonçaient des crimes dont la justice n'avait pas connaissance. Comment l'imam Châfi'i, mort il y a plus de mille ans, pouvait-il être tenu au courant de crimes que la justice officielle du pays ignorait? Cette affaire fit l'objet d'une enquête dirigée par le sociologue Sayyid 'Uways, enquête dont les résultats furent publiés en 1965 par le Centre National de la Recherche Scientifique et Criminologique ${ }^{19}$.

En dehors du Caire, Ahmad al-Badawî et Ibrâhîm al-Disûqî, respectivement enterrés à Tanta et à Disûq, dans le Delta, figurent parmi les saints fondateurs de confréries les plus populaires d'Égypte. Chaykh 'Abd al-'AI et chaykh al-Migâhid, l'un des premiers chaykhs de l'ordre Ahmadiyya, ont également leur tombe dans le mausolée de sayyid Badawi.

De toutes les commémorations, c'est le mawlid du Prophète, le 12 rabi' awwal, qui, symboliquement en tous cas, tient la place la plus importante ${ }^{20}$. C'est à cette occasion 
que les confréries déploient toutes ensemble leur plus grand faste. La procession soufie se rassemble habituellement à la mosquée Rifâ'iyya, au pied de la citadelle, pour se diriger vers la mosquée de Husayn, au coeur de la ville fatimide. Un rassemblement soufi a également lieu sur la place de Husayn avant de remonter la rue Al-Azhar vers Darrâsa, en direction de la Cité des Morts de Qâytbây. L'ensemble de la ville médiévale du Caire est alors livrée aux centaines de milliers d'Égyptiens venus fêter l'événement et qui se pressent autour des nombreux stands de friandises, tandis que les grandes places sont recouvertes de tentes de cérémonie où se pratique le dhikr. D'immenses tentes sont également dressées le long de la mosquée de Husayn, où chaykhs de confréries et représentants du gouvernement se côtoient pour les discours. Lors du dernier mawlid, Muhammad 'Alî Mahgûb, ministre des Waqf, y représentait Husnî Mubârak aux côtés du mufti de la République.

Le mawlid de Husayn, dans la seconde moitié du mois de rabi' thanî, dure 15 nuits et 14 jours. Le jour final en est toujours un mardi, plus particulièrement la nuit du mardi au mercredi. C'est le mawlid le plus important du Caire après celui du Prophète, généralement cinq ou six semaines après lequel il se tient. Le quartier de Gamâliyya est alors investi par une véritable marée humaine que les ruelles étroites ne permettent pas d'écouler. Transformée en immense terrain de foire où se pressent pèlerins, derviches et amoureux de la fête, la ville fatimide brille alors de tous ses feux, une débauche de guirlandes électriques multicolores illuminant le ciel. Les confréries, comme lors de chaque mawlid, installent leurs tentes dans les ruelles attenantes à la mosquée. C'est là que se déroulent les séances de dhikr, tandis que de nombreuses soupes populaires attirent une foule de nécessiteux.

En 1989, le mawlid de Husayn a rassemblé plus d'un demi-million de personnes. Le succès populaire de cette manifestation n'est pas sans susciter une certaine gêne. L'amour des gens du Caire pour le petit-fils du Prophète est parfois jugé excessif et on ne se fait pas faute de rappeler, parmi les ulémas, que c'est, en fait, Dieu et son Prophète qui sont aimés à travers le petit-fils du fondateur de l'islam. L'ambiguïté de la position du pouvoir est attestée par le fait qu'il encourage discrètement le mawlid, notamment en rendant gratuit le train pour les pèlerins qui s'y rendent, mais que la presse gouvernementale passe pratiquement totalement sous silence la manifestation. Le mawlid de Husayn devient ainsi un non événement: qu'un demi-million de personnes au moins se rassemblent dans un quartier du Caire ne fait même pas l'objet d'une mention dans les journaux. Une autre date, le 5 cha'bân, considérée comme le véritable jour de la naissance de Husayn, est l'occasion de cérémonies privées dans la mosquée.

Le mawlîd de Zaynab dure 15 jours et se termine le dernier mardi du mois de ragab. C'est le mawlid du Caire le troisième en importance après celui du Prophète et de Husayn. Comme pour le mawlid de Husayn, la mosquée qui abrite le tombeau de la sainte disparaît littéralement sous les guirlandes électriques, tandis qu'une foute énorme rend impraticable l'ensemble du quartier.

45 Les autres commémorations de saints personnages, tout en mobilisant pour certains des dizaines de milliers d'Égyptiens, revêtent toutefois une moindre importance. Le mawlid de l'imam Ahmad ar-Rifâ'i dure une dizaine de jours et se termine le premier vendredi de cha'bân. La grande procession soufie a lieu après la prière de l'après-midi, le jeudi, à partir de la mosquée de Sayyida Zaynab et se dirige vers la mosquée Rifầi. Le mawlid de sayyida Sakîna débute aux alentours du 12 gumâdâ ûlâ pour se terminer le 21 
gumâdâ ûlâ. Ceux de Hasan al-Anwar et de Sayyida Nafîsa, du 26 gumâdâ ûlâ au 4 gumâdâ akhira. Le mawlid de l'imam Châfi'i dure une dizaine de jours pour se terminer le premier ou le second mercredi de cha'bân. Sayyida Ruqayya est fêtée durant quatorze jours avant le premier jeudi du mois de gumâdâ akhira. Le mawlid de Fâtima Nabaweyya continue à être fréquenté, particulièrement par les femmes. Quant au mawlid de 'AIÎ Zayn al-'Abidîn, qui dure quatorze jours, il se termine à la fin de la troisième semaine de gumâdâ akhira.

En dehors du Caire, les deux plus grands pèlerinages sont ceux de Tanta et de Disûq. Il y avait, traditionnellement, trois mawlid de Sayyid Badawî à Tanta, fixés d'après le calendrier copte, ce qui fait que leur date était fixe d'année en année. On distinguait almawlid al-soghayyar, le 10 du mois copte de Tuba, c'est-à-dire vers le 17-18 janvier; le second, à l'équinoxe de printemps, al-mawlid al-wasit, lié à Sayyid 'Abd al-'Al, tombait toujours en barmûda ; le troisième, al-mawlid al-kabîr, le plus important, un mois et demi après le solstice d'été, avait lieu au milieu du mois de Abîb, au début d'août, lors de la crue du Nil. Chacun durait une semaine et un jour, commençant le vendredi et se terminant le vendredi suivant Aujourd'hui, les trois mawlid ont été regroupés en un seul, qui a lieu après la récolte du coton dans le Delta, au mois de bâbih, à une date qui correspond à la mi-octobre.

Les influences pharaoniques dans les mawlid de la Ahmadiyya ne se limitent pas aux choix des dates. Nombreuses sont les réminiscences de l'Égypte ancienne dans les rites et la façon de célébrer les morts. Le mawlid de Tanta est également l'occasion d'une immense foire commerciale, tandis que la ville est envahie par une foule dense. Manèges, spectacles de prestidigitateurs, vendeurs de bimbeloteries, de pâtisseries et de sucreries donnent à la cité une atmosphère de kermesse populaire. Ici et là, quelques loteries (yâ nasîb, assimilées à des jeux de hasard et, par conséquent, considérées comme illicites) voisinent avec les lieux de dévotion. Des tentes, dressées dans toute la ville pour chacune des nombreuses confréries, qui y organisent des séances de dhikr, accentuent encore l'indescriptible agitation de la cité. Le gouverneur de la province de Gharbiyya, représentant le président Husnî Mubârak, ainsi que tous les membres du Conseil supérieur soufi, assistent régulièrement au mawlid de Tanta. Les festivités se terminent avec plusieurs processions soufies. On estime que le nombre de pèlerins, lors du mawlid de Sayyid Badawi, dépasse aujourd'hui le million.

Une semaine après la fin du mawlid de Tanta débute le mawlid de Sîdî Ibrâhîm ad-Disûqî à Disûq. Celui-ci dure une semaine et un jour, pour se terminer le premier vendredi de rabi' thânî. De même qu'à Tanta, cette commémoration est prétexte à une immense fête foraine qui s'étire de la mosquée où est enterré le saint jusque sur les rives du Nil. Les sayyid de la Burhâmiyya y ont évidemment la première place, mais la Ahmadiyya, la Rifâ'iyya et la Châdhiliyya sont également très présentes. Le chaykh de la confrérie Magâhidiyya Burhâmiyya, juché sur un cheval blanc, conduit la procession soufie, le dernier vendredi après la prière de midi. Comme lors des grands mawlid, celui de Disûq est marqué par la présence des représentants civils et religieux de l'État, en l'occurrence le gouverneur de la province de Kafr al-Chaykh, ceux du ministère des Waqf et du mufti de la République. Le mawlid de Disûq rassemble beaucoup de monde, la municipalité de Disûq annonçant en 1989 qu'elle était prête à recevoir 2 millions de pèlerins. al-Rahîm al-Qenâwî̀ à Qenâ, organisé dans la première moitié de cha'bân par la confrérie 
locale Rahîmiyya Qenâ'iyya, celui de chaykh Abû-l-Haggâg al-Luqsurî, ainsi que celui de chaykh Sultan al-Sa'id al-Farghali à Abu Tîj. En outre, certaines mosquées comme celle de Charaf al-Dîn al-Bûsirî à Alexandrie, qui offre aux visiteurs la dépouille du compositeur du plus fameux poème à la louange du Prophète, ou celle de 'Amr ibn al-'As au Vieux-Caire, qui est considérée comme la première mosquée d'Égypte, sont régulièrement visitées et le lieu de pèlerinages annuels. Il faut ajouter, à cette liste des lieux de sainteté, les tombes des grands maîtres soufis d'Égypte: mis à part Ahmad alBadawi, Ibrâhîm al-Disûqî et Charaf al-Dîn al-Bûsîrî, déjà évoqués, les tombes d'Ibn alFârid et de Dhû'n-Nûn, dans la Cité des Morts du Caire (Qarâfa), d'Abû-l-Hasan alChâdhilî (une mosquée a été érigée là où il mourut en 1258, sur la route du pèlerinage de La Mecque dans le désert entre Qenâ et Luxor), d'Abû-l-'Abbâs al-Mursî (dont la mosquée se trouvé à Alexandrie) et d'Ibn 'Atallâh al-Skandarî, les promoteurs de la Châdhiliyya en Égypte, d'Ibn Daqîq al-'Id, d'Al-Hâfiz al-Mundhirî, et d'autres encore sont autant de lieux où l'on vient solliciter la baraka.

On voit combien les confréries, le culte des saints, les pèlerinages et la dévotion au Prophète sont intimement liés dans la piété populaire ${ }^{21}$. Certes, les grands mawlid rassemblent beaucoup plus de monde que les adeptes des confréries stricto sensu. La piété populaire déborde largement le cadre confrérique. Mais ces immenses foires n'en demeurent pas moins fortement marquées par la présence massive des confréries soufies. Les femmes, qui n'ont pas accès aux confréries, compensent cette interdiction lors des mawlid où elles sont particulièrement nombreuses.

51 L'institutionnalisation des confréries n'a apparemment pas eu d'influence sur l'affluence aux mawlid, qui demeure grande, malgré des fluctuations suivant les années, comme si la piété populaire semblait indifférente au cadre institutionnel où elle s'exprime. On ne voit pas ce qui pourrait empêcher des centaines de milliers - voire des millions - d'Égyptiens, ruraux comme citadins des classes populaires, de se diriger chaque année vers les mausolées de tel ou tel saint. Les mawlid continuent en effet à être considérés comme de véritables fatalités cycliques par une grande majorité d'Égyptiens. Interrogés sur le silence de la presse à propos de l'affluence record au mawlid de Husayn, de nombreux Égyptiens firent cette réponse : «On n'en parle pas parce que c'est normal ». Les médias vont-il, en effet, prendre la peine de mentionner le lever ou le coucher du soleil ? Le fait que certains des plus grands mawlid de province soient célébrés à des dates fixes de l'année, correspondant aux crues du Nil ou à la récolte $\mathrm{du}$ coton, renforce encore cette association des mawlid avec les dates importantes du calendrier solaire, notamment pour certains travaux agricoles qui sont les mêmes depuis les pharaons. Aussi n'est-il pas étonnant que certains chercheurs égyptiens, comme Sayyid 'Uways, aient mis en exergue la continuité existant dans le culte des morts depuis l'époque pharaonique jusqu'à nos jours ${ }^{22}$.

Il n'existe aucun texte qui interdise de commémorer la naissance d'un saint ou d'un membre de la famille du Prophète. Mais ces commémorations ont davantage un caractère de réjouissance sociale que de manifestation religieuse. Et il arrive souvent qu'elles soient l'occasion de rites antéislamiques, comme à Tanta et à Disûq. De plus, les pèlerinages s'étendent maintenant aux tombeaux des fondateurs de chaque ramification confrérique et même à leurs successeurs! Des voix s'élèvent pour mettre en doute leur utilité d'un point de vue religieux et social, tandis qu'on met en garde contre la foi en la baraka des saints et les superstitions attachées aux mawlid. La visite des tombes et les pèlerinages locaux, dans la mesure où ces pratiques amènent à vouer 
à des créatures un culte qui n'appartient qu'à Dieu, sont souvent dénoncés comme des innovations blâmables. Mais ces visites n'ont jamais été condamnées, en dehors du wahhabisme, d'une façon absolue et le sunnisme a admis l'intercession des saints.

Toutefois, les mawlid sont l'objet de consignes strictes. Les chaykhs des confréries officielles, réunis au siège du Conseil supérieur des confréries soufies, font l'objet, avant les plus grands mawlid, de recommandations de la part du chef suprême des confréries soufies. Pas de chants, pas de musique, pas de percussions, pas de danses dans les séances de dhikr, pas de mixité dans les réunions, interdiction d'avaler du feu, des insectes, des charbons ardents, des morceaux de verre ou des serpents vivants... ou de se frapper avec des épées! Les chaykhs soufis savent que le soufisme est jugé sur ces pratiques. Aussi essaient-ils de dégager leur responsabilité. Tout aussi rituels que les recommandations sont les communiqués du Conseil supérieur des confréries soufies à l'issue des plus grands mawlid pour déclarer: le soufisme n'est pas responsable des excès de certains.

54 La piété populaire qu'encadrent les confréries soufies n'a pas été atteinte par le processus d'institutionnalisation. Parallèlement, celui-ci a eu pour effet la reconnaissance de confréries de plus en plus nombreuses. Du milieu du xIX siècle à 1981, le nombre des confréries officielles a constamment augmenté :

on est passé de 20 confréries en 1848, à 33 en 1906, puis à 44 en 1948, à 60 en 1958, à 65 en 1968 et à 68 en mai 1979. Il y a aujourd'hui, en 1990,73 confréries soufies officiellement enregistrées. Les confréries les plus récemment reconnues sont la Qasabiyya Khalwatiyya (mai 1980), la Hâchimiyya Khalwatiyya (juillet 1980) et la Ga'fariyya Ahmadiyya Muhammadiyya (novembre 1986).

La progression dans ce mouvement de légalisation de nouveaux ordres n'a pas été constante. Entre 1958 et 1981, une dizaine de confréries ont été reconnues, mais c'est surtout sous le régime nassérien, à partir de 1954, que les interventions systématiques du pouvoir dans les affaires souries ont suscité un grand nombre de reconnaissances officielles. En août 1980, le Conseil supérieur des confréries soufies décida de ne plus reconnaître temporairement de nouvelles confréries à cause de la prolifération du nombre des confréries officielles, prolifération régulièrement dénoncée par les fondamentalistes comme un défi à l'unité musulmane. En attendant, on conseillait aux nouvelles confréries de s'affilier à celles possédant un statut légal. Mais cette décision n'a pas été respectée, puisque le processus a repris, quoique à un rythme beaucoup plus lent. Face à cette multiplication des confréries, chaykh Taftâzânî, le chef suprême actuel des confréries soufies déclare: "II est impossible d'unifier les nombreuses confréries, qui sont autant d'écoles spirituelles à l'histoire différente. » Le monde soufi est aussi une école de pluralisme, aucune confrérie ne revendiquant l'exclusivité de la légitimité,

57 Les 73 confréries officielles, dont la moitié sont nées au XIX ${ }^{e}$ siècle et 15 environ ont été fondées au $\mathrm{xx}^{\mathrm{e}}$ siècle, se répartissent comme suit: 19 confréries Khalwâtiyya, 18 Ahmadiyya, 18 Châdhiliyya, 6 Burhâmiyya, 2 Qâdiriyya, 2 Rifầiyya, 1 Naqchabandiyya et 1 Mîrghaniyya Khatamiyya. Mais il faut aussi compter les confréries non reconnues, affiliées ou non à des groupes légaux, et dont le nombre dépasserait la cinquantaine.

II y a donc probablement plus de cent vingt confréries soufies dont les membres sont répartis sur tous le territoire égyptien, à la ville comme à la campagne. Cependant, la réalité soufie est, très variable. Certaines confréries n'ont plus de chaykh depuis 
longtemps. D'autres, qui ont un chaykh, n'ont plus d'activités soufies. D'autres, qui ont chaykh et activités soufies, ne sont pas reconnues officiellement. Le nombre des adhérents peut varier de quelques centaines à plusieurs centaines de milliers. Les confréries sont, par nature, soumises à des fluctuations dues au caractère charismatique de leur leadership. Le déclin d'anciennes confréries importantes et l'émergence de nouveaux groupes confrériques semble être la règle.

Certaines confréries ont parfois leur propre périodique. Toutes publient des brochures contenant les prières rituelles (awrâd), des instructions religieuses générales et des données historiques et biographiques sur les saints de la confrérie. Enfin, il faut ajouter qu'un certain nombre des chaykhs influents n'ont pas voulu fonder d'organisation confrérique, dédaignant les voies de la reconnaissance officielle par le biais du Conseil supérieur des confréries soufies. Leurs adeptes sont connus comme Ahbâb al-chaykh... (les fidèles du chaykh...), qu'on voit apparaître lors des mawlid où ils sont tolérés, malgré les contraintes de la loi sur la mystique.

60 Le groupe social des chaykhs de confréries soufies a, quant à lui, profondément été transformé par l'intégration à l'administration de l'État. Un nouveau type de chaykh soufi est apparu, formé à Al-Azhar, et souvent en prise directe avec la réalité économique et sociale égyptienne. Il suffit de considérer le profil social et intellectuel des membres du Conseil supérieur des confréries soufies, pour voir qu'on est loin de l'image traditionnelle du derviche pauvre, sale et ignorant.

61 la meilleure illustration de ce nouveau profil du chaykh soufi est la personnalité de l'actuel chaykh machâyikh al-turuq al-sûfiyya.. Chaykh Abû-l-Wafâ al-Taftâzânî, qui a troqué la gallabeyya et le turban de ses prédécesseurs pour le costume et la cravate, a pris la tête de la confrérie Ghunaymiyya Knalwatiyya en 1947. Membre du Conseil supérieur soufi depuis 1952, il a accédé à sa fonction à la tête des confréries le 12 janvier 1983, à la mort de chaykh Sutûhî, son prédécesseur. Il est également depuis directeur de la revue Tasawwuf Islâmî. C'est un universitaire, doyen de la Faculté d'Education du Fayyûm, aujourd'hui vice-président de l'Université du Caire où il occupe une chaire de philosophie, il a obtenu une maitrise de philosophie en 1955 sur Ibn 'Atallâh al-Skandarî, puis un doctorat en 1961 sur Ibn Sab'in, un autre grand maître soufi originaire d'Andalousie. Symbole d'une ouverture nouvelle sur le monde extérieur, chaykh Taftâzânî a résidé successivement au Canada, en Espagne, au Liban, à Koweït, à Qatar, pays où il a enseigné pour des périodes plus ou moins longues. Ses conférences l'ont, d'autre part, amené en Belgique, en Allemagne, en France, en Italie, en Inde et en Arabie Saoudite.

Outre Taftâzânî, les chaykhs de confréries soufies membres du Conseil supérieur n'ont plus rien à voir avec l'image traditionnelle du chaykh analphabète. Dix d'entre eux ont été élus, ou plutôt réélus puisque la plupart ont été reconduits dans leur fonction, le jeudi 4 janvier 1990, date prévue pour le renouvellement de cette assemblée. Le Conseil actuel comprend, chaykh Taftâzânî inclus, quatre chaykhs Khalwatiyya, quatre chaykhs Ahmadiyya, un chaykh Rifầiyya. un chaykh Châdhiliyya et un chaykh Burhâmiyya. Parmi eux, on trouve quatre ulémas d'Al-Azhar, deux avocats, deux fonctionnaires, un journaliste et un homme d'affaires.

63 Certaines personnalités font désormais partie du paysage habituel du soufisme officiel, Sayyid Mahmûd Kâmil Yasin al-Rifâ'i, chaykh de la Rifâ'iyya, le numéro deux du Conseil, dont il est le plus ancien membre puisque régulièrement réélu depuis 1945, aujourd'hui vice-président du Conseil soufi, est un homme d'affaire important, P.D.G. 
de la compagnie de produits pharmaceutiques Suisse Pharma. En janvier 1989, il a été élu président du conseil d'administration du célèbre club de football Tarsâna. Il dirige un institut azharien lié à sa confrérie, inauguré en mai 1984, l'Institut Ahmad ar-Rifâ'i. Madame Fayda Kâmil, l'épouse du chaykh, est membre du Parlement. Chaykh Ahmad Sabrî al-Farghalî, chaykh de la Farghaliyya Ahmadiyya, azharien, réélu au Conseil soufi depuis plus de dix ans, est un bon exemple de la symbiose entre les cultures soufie et azharienne. Un autre azharien et uléma important, chaykh Mustafâ 'Abd al-Khâliq alChabrâwî, chaykh de la Chabrâwiyya Khalwatiyya, est membre du Conseil depuis 1952. Sayyid Ahmad Muhammad Chams al-Dîn, chaykh de la Marâziqa Ahmadiyya, avocat, secrétaire du conseil d'administration de la mosquée de Husayn, au Conseil depuis plus de dix ans, est membre du Parti national démocrate au pouvoir et, à ce titre, marque souvent de sa présence les cérémonies religieuses officielles.

'Uléma et azharien, tel est le cas également de sayyid Hasan Muhammad Sa'id alChinnâwî, chaykh de la Ahmadiyya Chinnâwiyya, ancien inspecteur général des Waqf dans la province de Gharbiyya et membre du Conseil depuis plus de dix ans. Sayyid 'Abd al-Rahîm Muhammad al-Gawharî, chaykh de la Gawhariyya Châdhiliyya, est quant à lui un journaliste connu. Enfin, sayyid Muhammad Salâma Nuwaytû, chaykh de la Kannâsiyya Ahmadiyya, directeur financier du Conseil, dont il n'est toutefois plus membre depuis 1987, est l'un des directeurs de la Banque sociale Nâsir, une importante institution bancaire islamique. D'autres ont été directeurs de société, comme Sa'id Mâhmûd al-Marzûqî, chaykh de la Madaniyya Châdhiliyya, qui occupa un poste de direction à la Société égyptienne d'égrenage du coton. D'autres ont occupé ou occupent des fonctions dans l'administration de l'État, à l'instar du chaykh de la Qasabiyya Khalwatiyya, sayyid Ahmad 'Abd al-Hâdî al-Qasabî, ancien ministre et gouverneur de la province de Gharbiyya.

Chefs de familles de sayyids, véritables clans, les chaykhs soufis détenaient traditionnellement, en sus d'une autorité religieuse, une puissance économique, sociale et politique. Le tarissement des sources de revenus (comme ceux des waqf, par suite des réformes successives depuis la révolution de 1952) a entraîné leur nécessaire adaptation aux nouvelles conditions économiques. Il y a toujours le commerce des Igâza, les permissions délivrées aux khalîfa du chaykh, ainsi que les donations plus ou moins obligatoires lors des mawlid d'un des saints de la confrérie, des grands mawlid ou des fêtes islamiques. Mais la fonctionnarisation les a obligés à trouver ailleurs des sources de revenus, en même temps qu'elle les contraignait à acquérir une culture minimale. Malgré les obstacles, les grandes familles soufies subsistent: la famille 'Achûr, qui dirige la Burhâmiyya depuis le sultan mamelouk Qâytbây, la famille Yâsîn, à la tête de la Rifâ'iyya, ou la famille Nuwaytû, qui fournit ses chaykhs à la Kannâsiyya Ahmadiyya. Citons également la famille Gawharî, qui dirigea l'ensemble de la Châdhiliyya en 1881, la famille Farghalî, qui a contrôlé longtemps l'important mausolée du sultan Abû-l-'Alâ, un saint enterré dans le quartier de Bûlâq au Caire, la famille Chinnâwî et les vieilles familles comme les Bakrî et les Sâdât.

L'institutionnalisation a rendu obligatoire tout un réseau de représentants des chaykhs et de l'assemblée générale des chaykhs de confréries soufies. Une véritable hiérarchie confrérique s'est établie, basée sur les divisions administratives, qui quadrille de façon très serrée tout le territoire égyptien. Les wakîl protègent les intérêts des confréries, remplacent le chaykh en son absence et contrôlent l'administration des lieux de pèlerinage au niveau de la province. Ils sont aidé par des naqîb, choisis par le chaykh 
parmi ses adeptes pour assumer différents services généraux au profit de la confrérie (garder les chaussures au moment de la prière ou du dhikr, organiser les processions, etc). Les nâ'ib font la liaison entre le chaykh et ses représentants locaux au niveau de la ville ou du bayt (groupe de zâwiya). Le khalîfa, enfin, l'échelon le plus bas, est nommé par le chaykh au niveau du balad, du village ou de la zâwiya, où il supervise en général, de façon directe, un lieu de pèlerinage. Le khalîfa al-khulafâ' a une position prééminente par rapport au simple khalîfa. En 1982, l'assemblée générale des chaykhs des confréries soufies avait 160 wakîl dans toute l'Égypte. Quant aux confréries, le nombre de leurs représentants varie selon leur importance, mais il peut atteindre, tous échelons confondus, plusieurs milliers. Ainsi, une confrérie d'importance moyenne, la Bayyûmiyya Ahmadiyya avait, en 1982, 250 nâ'ib, 150 khulafâ' al-khulafâ' et 4000 khalîfa. La Farghaliyya Ahmadiyya avait, la même année, 100 nẩib en Égypte pour 2000 khalîfa.

Causes de déclin ou causes de renaissance : les confréries soufies face aux défis de la modernité

Comme la plupart des voyageurs, le Britannique Heyworth-Dunne a constaté et décrit le rôle central des confréries soufies en Égypte au XVIII ${ }^{\mathrm{e}}$ et au début du XIX ${ }^{\mathrm{e}}$ siècle $^{23}$. Aujourd'hui, piété populaire et soufisme continuent à mobiliser des foules immenses. Pourtant, dans les années 1960 et 1970, les chercheurs qui se sont intéressés au soufisme étaient unanimes dans leur pronostic pessimiste. A en croire le Père Anawati ${ }^{24}$, Bannerth ${ }^{25}$, Gilsenan ${ }^{26}$ ou Trimingham ${ }^{27}$, les confréries souftes en Égypte avaient perdu la place privilégiée qu'elles occupaient et ne jouaient plus qu'un rôle marginal. Les mêmes mettaient en avant, comme facteurs de ce déclin, la faiblesse majeure des confréries qui réside dans leur structure organisationnelle, mais aussi leur éthique religieuse et sociale. En bref, le problème de l'inadaptation des confréries soufies aux défis de la modernité était posé28.

L'organisation confrérique soufie demeure, il est vrai, basée sur un mode d'allégeance particulier. La nature charismatique du pouvoir du chaykh a un grave défaut. Le charisme personnel joue, en effet, contre la stabilité organisationnelle. Weber avait déjà remarqué qu'un groupe fondé sur une autorité charismatique est rétif par nature à toute autorité rationnelle et bureaucratique. En Égypte, les khalifa jouissent le plus souvent d'une grande liberté sur les zâwiya et ne se sentent pas ou peu contrôlés par leur chaykh. Les confréries sont, traditionnellement, davantage une addition de centres locaux aux liens distants, où la solidarité organisationnelle tourne autour de la zâwiya plus qu'en référence à l'organisation confrérique. De plus, à cause du faible niveau de différenciation entre confréries, accentué par le bas niveau culturel des adeptes et l'ignorance généralisée en ce qui concerne la spécificité du corpus doctrinaire de chaque ordre, l'appartenance à plusieurs confréries est fréquente. En conséquence, les crises et les scissions sont courantes, surtout lors des successions.

La prolifération de branches autour d'individus charismatiques, véritable plaie du soufisme égyptien, se poursuit jusqu'à nos jours à un rythme incontrôlable. Cette faible cohésion n'est pas un facteur positif à un moment où beaucoup d'Égyptiens sont à la recherche d'un cadre communautaire et où les confréries doivent faire face à des critiques de plus en plus acerbes sous l'effet de l'influence croissante du fondamentalisme. L'absence de centralisation, l'autonomie locale des khalifa, la tendance chronique à se diviser sont un important facteur de déclin, qui a effectivement touché de nombreuses confréries autrefois influentes. 
70 Le recrutement des confréries se faisait traditionnellement par réseaux familiaux, de quartier, grâce à la pratique de l'endogamie et, bien que plus rarement, par prosélytisme lors des mawlid et des séances de dhikr. Le renouvellement des membres était déterminé par l'appartenance à des groupes sociaux donnés et quasi-automatique. On naissait châdhilî ou rifâ'i.

71 Les bouleversements sociaux des dernières décennies, avec l'émergence de nouvelles classes sociales et la relative dislocation du tissu traditionnel, a changé cet état de symbiose entre confrérie et structure sociale traditionnelle. Dès lors, le renouvellement de la confrérie par les canaux habituels n'est plus assuré. Les confréries, aujourd'hui, ne peuvent plus compter uniquement sur l'adhésion automatique de groupes sociaux. De plus, elles ne sont plus les seules institutions musulmanes. D'autres associations sont apparues, porteuses d'un projet social et politique. L'émergence de nouvelles classes moyennes s'est produite au moment où les confréries n'étaient plus, en ce qui concerne leurs moyens, la première institution sociale musulmane. A la recherche d'un projet politique, ces classes n'ont pas ou très peu été attirées par les confréries. C'est donc dans les milieux populaires que celles-ci ont continué à recruter, parmi ceux qui ne trouvent pas de place dans le nouvel ordre moderne, ce qui a encore augmenté le risque de leur marginalisation.

72 Le fait que les soufis se désintéressent, dans la plupart des cas, des problèmes sociaux et politiques qui sont au centre de la réflexion des courants modernes et fondamentalistes, a permis un tir nourri dirigé contre eux. L'absence de participation des confréries aux activités économiques et productives, leur apathie et leur passivité leur furent reprochées comme une cause du sous-développement. Symptomatique de cet état d'esprit largement répandu, une thèse de doctorat sur le soufisme soutenue en 1989 par un étudiant de Minyâ pose ainsi la question ${ }^{29}$ : «Le soufisme en Égypte a-t-il favorisé le travail, les activités sociales, la réussite commerciale et la participation à la production?» Et de répondre: «II est du devoir du gouvernement d'inciter les confréries soufies à s'impliquer davantage dans des activités sociales, afin qu'elles apportent leur participation à l'effort de développement. Les confréries pourraient rendre d'inappréciables services au développement du pays, surtout lorsqu'on songe qu'il y a au moins cinq millions de soufis en Égypte. »

73 Les fonctions sociales des confréries, il est vrai, ont été peu à peu occupées par l'État, d'autres associations ou par les élites religieuses et intellectuelles. Ecoles, hospices, accueil sont aujourd'hui en principe assumés par les autorités civiles. Les chaykhs soufis ont perdu le rôle important qui était le leur pour l'enseignement de la religion et la relation de maître à disciple n'est plus acceptée comme autrefois. Pour les gens cultivés, il existe maintenant d'autres canaux de socialisation. Face aux changements, écrit Michael Gilsenan, les confréries n'ont rien proposé d'autre que « la persistance des superstitions, des images et des pratiques dégradantes pour l'islam.» Le fait qu'elles fassent principalement appel aux illettrés, aux fellah et aux artisans des villes explique, selon cet auteur, l'absence de réponse de leur part aux défis du temps. «Elles durent, écrit-il, grâce à la persistance des attitudes passives et conservatrices de la société égyptienne. » Dès lors, l'apathie et le retrait des confréries lui semblaient un phénomène irréversible.

74 A cela, il faut ajouter que le tarissement des sources de revenus peut entraîner le déclin d'une confrérie. Les réformes successives des waqf ont eu leur point d'orgue en septembre 1981, lorsque les mosquées des confréries ont, au même titre que toutes les 
mosquées privées, été mises sous l'autorité du ministère des Waqf. Ces mesures faisaient suite à la réforme du système des waqf, mise en place en 1952,1953 et 1954, avec notamment l'abolition des waqf ahliyya, autant de décisions qui eurent des conséquences financières graves pour les chaykhs soufis. Crise de recrutement, perte de prestige, diminution de la richesse, autant de facteurs qui permettent à J. Spencer Trimingham d'écrire en 1971: «Bientôt, le soufisme populaire aura vécu.» Et M. Gilsenan d'ajouter: «Les nouvelles classes moyennes se tournent maintenant vers les groupes salafistes, Hasan al-Banna ou la Gama'iyyat al-chubbân al-MusIimîn (l'Association des Jeunes Musulmans). »

Ces mêmes chercheurs opposent le "déclin " des confréries soufies à partir de la première moitié $\mathrm{du} \mathrm{xx}^{\mathrm{e}}$ siècle à l'émergence de courants modernes, sécularisés ou islamiques, rationnalistes et hostiles au soufisme. Il est vrai que la floraison d'organisations islamiques aptes à capter l'attention des nouvelles couches sociales, dans les années 20 et 30, a représenté un véritable défi pour les confréries mystiques. Qu'il s'agisse de la Gama'iyyat Ahl al-Bayt (l'Association des Gens de la Famille du Prophète), de la Gama'iyyat Ansâr al-Sunna al-Muhammadiyya (l'Association des Partisans de la Sunna Muhammadienne), fondée en 1926 et qui publie depuis 1973 la revue mensuelle Al-Tawhîd, de la Gamâ'at Da'wa al-Haqq (l'Assemblée de la Prédication de la Vérité), de la Gama'iyyat Abu Bakr Siddîq (l'Association d'Abou Bakr), de la Gama'iyyat alKhulafâ' al-Râchidîn (l'Association des Califes bien dirigés) de chaykh Salmân Rabî' ou encore de la Gama'iyyat chabâb Sayyidna Muhammad (l'Association des Jeunes de Muhammad) de Muhammad 'Atiya Khamîs, toutes venaient rejoindre la Gama'iyyat alchubbân al-MusIimîn, créée en 1927, sans parier des Frères musulmans, pour défendre un islam sunnite moderne, réformiste et opposé à l'éthique soufie des confréries.

Le slogan principal de la relecture moderne de l'islam telle que l'ont conçue les réformistes, et qui est relayée aujourd'hui par les médias et l'enseignement, est l'« épuration de l'islam » et le retour au Coran et à la sunna, une stricte adhésion à la lettre du discours coranique et un refus total de toute autre interprétation. Les soufis ont été la cible principale de cette relecture. Le pamphlet de Muhammad Fahmi 'Abd alLatîf, Al-Sayyid al-Badawî wa Dawlat al-Darâwîch fî Masr (Sayyid Badawi et l'État des derviches en Égypte), d'abord publié en 1947 puis réédité en 1979, illustre bien l'âpreté d'un combat où les confréries apparaissent désarmées ${ }^{30}$. L'auteur y dénonçait "l'invraisemblable ramification de la Ahmadiyya, qui est un défi à l'islam» et le laxisme de l'État face à cet ordre, assurant que les autorités égyptiennes "s'étaient soumises face aux derviches. » Lorsque ce livre fut publié, le prêcheur de la mosquée Ahmadiyya le qualifia de livre impie. Mais chaykh Hâmid al-Faqî, le chef de la Gama'iyyat Ansâr al-Sunna al-MuhammadIyya, n'eut pas de mots assez forts pour louer le pamphlet, affirmant qu'il était «juste dans la mesure où il s'attaquait aux superstitions. » Dénonçant les réminiscences païennes des mawlid de Tanta, ainsi que «les influences juives et chrétiennes qu'ils manifestent », Muhammad Fahmî 'Abd alLatîf critiquait la présence d'officiels gouvernementaux à ces mawlid, ainsi que le soin apporté à l'entretien du tombeau de sayyid Badawî, que les soufis, dit-il, « considèrent comme une seconde Mecque.» Déplorant l'influence considérable des confréries, il mettait en garde contre « la nocivité, pour la société égyptienne, des derviches et des chaykhs, qui créent une situation favorable au colonialisme. »

Parmi les nombreux reproches adressés aux confréries, il y a la question de la transmission héréditaire de la fonction de chaykh. Jusqu'en 1976, la loi prévoyait que la 
succession d'un chaykh soufi devait être héréditaire selon un ordre de succession préétabli en fonction du lien de parenté. Le fils aîné devait obligatoirement succéder à son père, puis le second fils. En cas d'impossibilité, c'était ensuite le frère du chaykh défunt, ou un neveu, puis un proche parent, à qui revenait d'assumer la fonction du disparu. Si le nouveau chaykh se trouvait avoir moins de 20 ans, un conseil de régence le remplaçait jusqu'à sa maturité.

La loi 118 de 1976 a modifié cet état de fait : tout en réaffirmant le principe héréditaire, elle y met comme condition la capacité réelle de la personne. S'il s'avère qu'aucun membre au sein de la famille du chaykh n'est apte à la succession, c'est parmi ses adeptes qu'on doit choisir le nouveau chaykh. Chaykh Taftâzânî pense que le principe de la transmission héréditaire doit s'effacer au profit du choix du plus capable.

La loi égyptienne concernant les confréries soufies n'impose donc plus la succession héréditaire. Pourtant, celle-ci continue à être la règle, l'écrasante majorité des successions se faisant sans tenir compte des qualités religieuses et des capacités du nouveau promu. Cette pratique a été la cible des attaques de certains ulémas et des fondamentalistes qui la qualifient de contraire à l'islam.

Pourquoi ne pas élire les chaykhs de confrérie? «C'est la capacité qui compte pour être un bon chaykh et non sa lignée ", affirme-t-on dans ces milieux. L'imam de la mosquée de Husayn, Ahmad Farhât, est, pour sa part, favorable à l'application du principe islamique de la chûrâ (consultation) lors de la transmission de la fonction de chaykh soufi. Le journal Al-Liwấ' al-islâmi (La bannière islamique), publié par le Parti national démocrate mais qui reflète des positions proches des Frères musulmans, ajoute : « Nous ne sommes pas des chiites qui font reposer toute la légitimité sur la succession héréditaire. Le soufisme doit se débarrasser de ce principe chiite, car nous sommes sunnites. Or, dans la loi égyptienne de 1976 (loi 118), ce principe de succession héréditaire, bien qu'atténué, est réaffirmé, alors qu'il contredit les principes de l'islam ${ }^{31}$.»

81 L'équation entre chaykh soufi et Imam chiite fait maintenant partie de l'arsenal traditionnel des arguments avancés par les adversaires du soufisme. La transmission héréditaire de la baraka, déclarent les tenants d'un islam orthodoxe, conduit à l'idolâtrie. «Le principe de la succession est utilisé pour sacraliser une famille et figer le soufisme dans des pratiques magiques. »... La succession héréditaire, ajoutent-ils, " permet de garder au sein de la même famille l'honneur et l'argent qui sont attachés à la direction d'une confrérie ${ }^{32}$.» Or, si ces arguments ont une certaine vérité, ceux qui les avancent ne le font pas innocemment. Ils savent qu'abroger la transmission héréditaire de la fonction de chaykh porterait directement atteinte au charisme du chaykh soufi, attaché à la baraka du saint fondateur. Ce charisme n'est pas uniquement fonction de la science du chaykh, mais du pouvoir transmis par son ancêtre.

Autre défi de la modernité auquel ont été confrontées les confréries soufies: l'intégration à l'État et le rapport à la politique qui en découlait La faiblesse organisationnelle des confréries soufies en a fait une proie apparemment facile pour l'État. L'institutionnalisation du soufisme a paru signifier une domestication sans partage de celui-ci. C'est la classe des chaykhs soufis qui en a été l'instrument. Fragilisée par des crises internes perpétuelles, celle-ci a accueilli favorablement ce processus. Les chaykhs soufis ont, en effet, besoin de l'autorité de l'État pour s'imposer face à leurs concurrents au sein de la confrérie, mais aussi face aux détracteurs du soufisme. L'État a besoin des chaykhs soufis, dont la clientèle demeure immense et qui 
lui offrent une légitimité islamique nécessaire face à la surenchère de groupes fondamentalistes. Il s'agit donc d'un besoin réciproque. On peut, à partir de là, définir le rapport utilitaire du soufisme à la politique. Les confréries manifesteront un soutien permanent à l'État, qui les cautionne et les protège, soutien qui se démentira de moins en moins au fur et à mesure qu'elles seront incorporées à ses institutions.

L'objectif de chaque chaykh soufi est désormais de faire reconnaître officiellement sa confrérie. Une reconnaissance officielle, en plus du fait qu'elle établit l'autorité du chaykh contre les mouvements sécessionnistes, lui apporte d'appréciables bénéfices financiers et le droit de participer aux cérémonies religieuses publiques. Depuis 1895, date à laquelle le Conseil soufi fut la juridiction suprême dotée du pouvoir de reconnaître les nouvelles confréries soufies, celles-ci sont presque naturellement devenues une clientèle politique. Avant la révolution de 1952, le Palais, comme les Britanniques ou les partis politiques, ont ainsi largement eu recours aux confréries soufies avant que celles-ci ne deviennent la base islamique du régime nassérien ${ }^{33}$.

Depuis que les partis existent en Égypte, ils ont courtisé les confréries. Entre 1907 et 1957, plusieurs d'entre elles obtinrent leur reconnaissance officielle grâce aux relations avec certains partis politiques qui exercèrent les pressions adéquates sur le chef suprême des confréries soufies. Un cas notable fut celui de la 'Azamiyya Châdhiliyya, fondé par Muhammad Mâdî Abû-l-'Azâ'im. La 'Azamiyya fut reconnue en avril 1933 grâce à l'intervention, auprès de chaykh 'Abd al-Hamîd al-Bakrî, alors chef suprême des confréries, de Muhammad Mahmûd, le dirigeant du Parti des Libéraux Constitutionnalistes (Hizb al-Ahrâr al-Dustûriyyîn). Pendant ce temps, Mahmûd Abui-'Azâ'im, frère du précédent, obtenait le soutien d'un autre politicien, Ismâ'il Sidqî, le mentor du Parti du Peuple (Hizb al-Cha'b). Ce dernier avait entrepris une véritable opération de charme envers les confréries soufies afin de bénéficier de leurs voix. La véritable course de vitesse entre les deux frères pour obtenir la reconnaissance de leur confrérie, chacun avec l'appui de partis politiques, se termina à l'avantage de Mahmûd, qui obtint le premier un statut officiel, mais mourut la même année en 1935. Le fondateur de la 'Azamiyya eut dès lors la voie libre.

Un autre ordre dut sa reconnaissance grâce à l'intervention de partis politiques: la Habîbiyya, originellement une branche de la Rifâ'iyya, Chaykh Mahmûd 'Abd al-'Aziz Yâsîn, le chef de la Rifâ'iyya, s'étant opposé à la reconnaissance de la Habîbiyya, celle-ci eut recours à des politiciens pour se faire attribuer un statut légal. Quant au Wafd, il intervint dans un litige à propos de la succession à la fonction de chaykh al-saggâda de la 'Afîfiyya Châdhiliyya. C'est ainsi que naquit la 'Afifiyya Hâchimiyya Châdhiliyya, auquel le Wafd permit d'exister face à l'ancienne confrérie-mère.

La clientèle soufie était largement utilisée dans la mobilisation électorale en faveur de tel ou tel parti et servit de tremplin à la carrière politique de certains chaykhs soufis. Ainsi, chaykh Muhammad Mahmûd 'llwân fut, entre 1942 et 1953, membre du Parlement où il représentait le Parti al-Sa'adî. C'est le soutien de sa confrérie qui lui avait permis de remporter le siège brigué. Par ailleurs, plusieurs tentatives furent faites par le Wafd pour asseoir un contrôle direct sur la présidence du Conseil soufi, C'est ainsi qu'en 1946, Mustafa al-Nahhâs avança ses pions. Ahmad Murâd al-Bakrî ayant été déposé par le roi Fârûq pour son soutien apporté au mouvement anti-égyptien au Soudan, Nahhâs poussa " son » chaykh vers la présidence du Conseil soufi. L'entreprise aurait réussi, n'avait été la rétractation du chaykh, son protégé, qui se refusa à n'être qu'un simple instrument politique. C'est Ahmad aI-Sawî qui dirigea finalement le 
Conseil à partir de 1847. Sous son mandat, le chef des Bektachîs d'Égypte fut de facto admis parmi les dirigeants des confréries soufies, illustrant les rapports privilégiés entre le Palais, notamment Fârûq, et cette confrérie. L'origine turco-albanaise des Bektachîs semble avoir joué un rôle dans les relations spéciales entre la Cour et cette secte. A partir de 1905, les Bektachîs étaient apparus comme le catalyseur du nationalisme albanais et les khédives, notamment Fu'âd, avaient cherché à faire valoir leur droit sur le trône d'Albanie, grâce à leurs relations avec les Bektachîs.

Les Britanniques, de leur côté, firent pression pour la reconnaissance de la Damîrdhâchiyya et de la Ghunaymiyya. La Ghunaymiyya était originellement une branche de la Rifâ'iyya. Grâce aux Britanniques. Taftâzânî, le père de l'actuel chef suprême des confréries soufies, obtint la reconnaissance de sa confrérie en 1926. Quant à la Mîrgnaniyya-Khatamiyya, qui s'était opposée au mahdisme au Soudan, elle recevait d'importants subsides des Britanniques en remerciement pour ses activités antimahdistes. La Idrîsiyya figurait également parmi les confréries bénéficiant des largesses britanniques. Seuls Muhammad Mâdî Abû-l-'Azâ'im et Mahmûd Abû'l-Fâyyid al-Minûfî, parmi les chaykhs soufis, sont connus pour s'être opposés aux Britanniques.

Dans le cas d'Abû-l-'Azâ'im, ses activités antibritanniques semblent n'avoir couvert que la période de la révolution de 1919. Il permit à l'organisation terroriste antibritannique, la Gama'iyyat al-Yad aI-Sûdâ (La Main Noire) d'utiliser son imprimerie. Arrêté alors à plusieurs reprises, il fut cependant vite relâché. Quant à Mahmûd Abû-l-Fayd al-Minûfî, il fut davantage engagé dans l'action antibritannique à la tête de son organisation, la Gama'iyyat al-Faydiyyîn, qui publia, de 1924 à 1930, le mensuel Liwâ' al-lslam (Le Drapeau de l'Islam). Son groupe fut officiellement reconnu comme confrérie soufie en 1950, en tant que branche de la Châdhiliyya. Aucune mesure de rétorsion ne fut prise par les Britanniques à l'égard de la 'Azamiyya et de la Faydiyya.

A l'époque de Nasser, le nouveau régime réalisa rapidement l'intérêt qu'il avait à mobiliser en sa faveur cet énorme potentiel représenté par les confréries soufies, à un moment où il était à la recherche d'une légitimité islamique face aux Frères musulmans $s^{34}$. Pour cela, il lui fallait neutraliser le mouvement de réforme qui s'était affirmé parmi les confréries depuis 1947 sous l'impulsion de chaykh Ahmad as-Sawî, et favoriser, au contraire, l'aspect populaire de l'islam soufi avec lequel il pouvait trouver une communauté de langage. Chaykh Ahmad al-Sawî fut démis de ses fonctions en 1957 et remplacé par chaykh Muhammad Mahmûd 'llwân, chaykh de la confrérie 'llwâniyya. Le nouveau chef suprême des confréries soufies, un proche du maréchal 'Amir, qui dirigera le monde soufi durant toute l'ère nassérienne, sera le symbole même du soutien total des confréries au régime ${ }^{35}$. Sous sa présidence, le Conseil soufi ira jusqu'à reprendre à son compte la langue de bois de la propagande officielle, dont la revue Allslâm wa-l-Tasawwuf fut le porte-parole fidèle, et d'importantes confréries se feront l'écho de tous les thèmes de mobilisation décrétés par le pouvoir. Le soufisme fut systématiquement utilisé par ce dernier à des fins de politique intérieure, mais aussi étrangère. Tandis que plusieurs confréries favorisées par les autorités étaient reconnues, le nombre et l'ampleur des mawlid augmentèrent avec la bénédiction du régime et les confréries furent associées à toutes les célébrations religieuses. Depuis sa création en 1961, l'Union Socialiste Arabe s'était impliquée dans l'organisation de ces célébrations et en profitait pour diffuser sa propagande. Le mawlid de sayyid Badawî à Tanta devint ainsi une tribune pour les dirigeants du pays. Un certificat de l'Union 
Socialiste Arabe fut exigé pour être nommé chaykh de confrérie ou membre du Conseil soufi. La permission du ministère des Waqf pour tenir des hadra fut également requise.

Les interventions croissantes du régime nassérien dans les affaires des confréries soufies illustrent deux soucis : empêcher la perpétuation ou l'affirmation d'une autorité importante échappant à son contrôle et mobiliser les adeptes du soufisme en soutien au régime. C'est la raison pour laquelle le pouvoir fut vigilant à empêcher toute friction avec les confréries, ce qui explique l'absence de mesures à rencontre des chaykhs qui avaient été les protégés du Palais et de la Cour. Certains chaykhs soufis devinrent à leur tour les protégés du nouveau régime. Tel fut le cas de chaykh Ahmad Ridwân, à la tête d'un groupe soufi non confrérique, qui, à la fin de sa vie en 1967, était probablement le chaykh le plus vénéré de Haute-Égypte et, peut-être, de toute l'Égypte. Conseiller spirituel de Nasser, on lui attribua le rôle d'un Raspoutine.

91 Une autre confrérie doit beaucoup à la position politique de ses chaykhs à l'époque nassérienne : la Khalîliyya, une branche de la Bayyûmiyya. Mahmûd Abu Khalîl obtint la reconnaissance de sa confrérie en 1963 grâce à ses relations au sein de l'Union Socialiste Arabe et à son amitié avec Muhammad Mahmûd 'llwàn. La convergence des intérêts entre le pouvoir et les chaykhs soufis fut également illustrée par le cas de la Hâmidiyya Châdhiliyya. Parmi les privilèges dont bénéficia cette confrérie, il y eut le droit de marcher en tête des processions, malgré le fait que ce droit était traditionnellement l'apanage de la Sa'adiyya. Le chaykh de la confrérie, Ibrâhîm Salâma al-Râdî (mort en 1967), avait un accès direct aux plus hautes sphères de l'Etal où se retrouvaient plusieurs de ses adeptes.

Quatre exceptions figurent au tableau de ces relations idylliques: les Bektachîs et la Damîrdâchiyya, qui se virent porter un coup fatal, et dans une moindre mesure, la Hisâfiyya et une branche de la Naqchabandiyya. En ce qui concerne les Bektachîs, trop compromis avec le régime des khédives, leur tékkiyé, sur les contreforts du Muqattam, leur fut confisquée en 1957 et le terrain fut incorporé à une zone militaire. A l'instar du sultan-calife ottoman Mahmûd II, qui avait supprimé en 1826 la Bektachiyya à cause de ses liens avec les janissaires, Nasser décidait à son tour d'éliminer cet ordre pour des raisons politiques. Privée de toute ressource, la secte cessa d'exister en Égypte à la mort d'Ahmad Sirrî Dede Baba. en 1965.

Autre confrérie qui dut souffrir du régime nassérien : la Damîrdâchiyya, qui possédait de nombreux immeubles dans le centre du Caire. Lorsque ces biens furent confisqués en 1961, la famille dirigeante de la Damîrdâchiyya décida de ne pas rentrer en Égypte tant que le régime nassérien serait en place. La confrérie vit son importance décroître et ne devait pas se remettre des mesures prises à son encontre. Un autre ordre demeurait suspect aux yeux du régime nassérien : la Hisâfiyya, à cause de la présence passée de Hasan al-Bannâ dans ses rangs. Lorsque Hasan al-Bannâ fonda les Frères musulmans en 1928, il fut expulsé de la Hisâfiyya par son chaykh, Muhammad 'Abd al-Wahhâb alHisâfî, qui l'accusa d'activités scissionistes. Le chaykh interdit tout contact entre les adeptes de la Hisâfiyya et les Frères musulmans, mais cette interdiction ne fut pas respectée. Ahmad al-Sukkârî, un proche de Hasan al-Bannâ, avait quitté les Frères musulmans en 1947 pour retourner à la Hisâfiyya, mais les contacts demeurèrent étroits, d'où les craintes du régime. La Hisâfiyya continua à compter de nombreux-exFrères musulmans dans ses rangs, ce qui l'empêcha d'obtenir une reconnaissance officielle. Son influence s'en ressentit fortement. 

Burhâniyya Disûqiyya Châdhiliyya, se vit encouragée en partie pour son utilité à cimenter les relations de l'Égypte avec le Soudan. Cette confrérie était dirigée par un Soudanais, Munammad 'Uthmân 'Abduh, résidant à Khartoum. En Égypte, son représentant était Gamâl ad-Dîn al-Sanhûri, lui aussi Soudanais et ancien secrétaire personnel de Salâh Sâlim à l'époque où celui-ci était ministre de l'Orientation nationale. Depuis 1947, Munammad 'Uthmân 'Abduh était le nâ'ib officiel à Khartoum de la Burhâmiyya, dirigée par la famille 'Achûr au Caire. Son ascension au Soudan en tant que chef de facto d'une confrérie soufie indépendante, même si elle continuait en droit à dépendre de la Burhâmiyya, semble avoir été le résultat du soutien prodigué par les milieux pro-égyptiens, dans la mesure où on le considéra apte à reprendre la tête des forces favorables à l'union avec l'Égypte, à la mort de 'Alî al-Mîrghanî en 1968. La Conférence soufie mondiale du Caire en 1961, qui rassembla des chaykhs soufis de tous les pays arabes, répondait au même souci du régime d'exploiter à son profit les réseaux arabes de la mystique organisée.

Une autre confrérie soufie, suspectée d'abriter d'anciens membres des Frères musulmans, figure parmi celles qui durent subir les rigueurs de la répression: la Naqchabandiyya de Nagm al-Dîn al-Kurdî. En 1965, ce dernier fut arrêté et sa confrérie interdite. Ce chaykh, impliqué par ailleurs dans un soutien actif au mouvement kurde en Irak, avait réussi à attirer un grand nombre d'adeptes au Fayyûm et à Banî Sueîf. L'interdiction s'expliquait autant par les relations présumées avec les fondamentalistes que par le souci de ne pas envenimer les relations avec Baghdad après la disparition de Qâsim, le grand rival de Nasser. A partir de 1967, toutes les restrictions concernant alKurdî et son groupe furent levées, mais sa confrérie n'obtint pas de reconnaissance.

base populaire dans des buts de politique extérieure, profilant du caractère supranational de certains ordres. C'est dans ce sens qu'il faut comprendre l'action du chaykh de la Gunaydiyya Khalwatiyya, confrérie fondée par un Syrien au milieu du XIX siècle. A l'automne de l'année 1958, Husayn Ibrâhîm al-Gunaydî fit un long séjour en Syrie, non seulement en sa qualité de chaykh soufi, mais aussi en tant qu'ancien membre de l'Assemblée nationale égyptienne, dissoute dès la création de la R.A.U. le 1er lévrier 1958, II y fonda la 'Achîra Gunaydiyya qui aurait compté 50000 membres à Damas et à Alep. La mission assignée à ce chaykh était visiblement de cultiver les liens existant entre l'Égypte et la Syrie. C'est probablement ce qui explique la reconnaissance rapide de sa confrérie en Égypte, Avec la petite confrérie Kattâniyya Châdhiliyya, le régime nassérien tenta de resserrer les liens envers un autre pays arabe, en l'occurence le Maroc, pays d'origine de la confrérie.

A l'instar de ce qui s'était déjà produit sous les khédives, il semble que, si le pouvoir a utilisé les confréries soufies selon ses intérêts, les chaykhs des confréries ont à leur tour largement exploité les possibilités que leur laissait le pouvoir pour consolider leur autorité sur leur confrérie ou pour se lancer dans la politique. Aucun chaykh soufi ne fut certainement autant impliqué politiquement que celui de la Gunaydiyya. Membre de l'Assemblée nationale en 1957-58, puis de l'Assemblée du Peuple à trois reprises, en 1964,1968 et 1971, membre de l'Union Socialiste Arabe, il dut ses élections successives au soutien de ses adeptes. Lorsque le chaykh de la Gunaydiyya fut contesté par l'un de ses khalifa, qui fonda sa propre confrérie, la Gûdiyya, tout en dénonçant l'illégitimité du leadership de la Gunaydiyya, Husayn al-Gunaydî dut à ses appuis politiques de 
conserver le contrôle et l'indépendance de sa confrérie. D'autres chaykhs furent également élus à l'Assemblée du Peuple grâce à la mobilisation de leurs adeptes : ce fut le cas de Kâmil 'Abd al-Gawâd al-Qayâtî, chaykn de la Qayâtiyya Khalwatiyya. ainsi que de Sâlih al-Ahmadî al-Chabrâwî, chaykh de la Chabrâwiyya Khalwatiyya. Localement, des nẩib et des khalîfa furent élus sur des listes de l'Union Socialiste Arabe à des postes de responsabilité dans l'administration provinciale des gouvernorats. La Husayniyya Châdhiliyya obtint du ministère des Waqf les autorisations de pratiquer le dhikr et de participer aux mawlid, sans passer par le Conseil soufi, grâce aux relations de son chaykh, Gâbir al-Gazûlî, avec le parti au pouvoir. Toutefois, cette confrérie ne fut pas reconnue. Les relations politiques ont pu aussi protéger les confréries sans statut des appétits des confréries officielles.

98 Les confréries soufies ont soutenu la politique intérieure et extérieure de Nasser dans la plupart de ses aspects. Elles se rangèrent sans ambiguïté du côté des autorités lorsque celles-ci affrontèrent les Frères musulmans. Les confréries permirent sans conteste de maintenir éloignée de la violence et du refus du régime, qui caractérisaient alors certains courants islamiques, une proportion non négligeable de l'opinion musulmane. Ainsi, les confréries soufies ont accepté le socialisme nassérien, la démocratie et le nationalisme arabe. La justice, thème récurrent de l'idéologie socialiste, fut considérée comme une vertu musulmane. Lorsque la question d'une nouvelle constitution fut discutée, les confréries se contentèrent d'insister pour que la charîa soit la source des lois. Mais il leur suffisait visiblement que l'islam soit proclamé religion d'État, sans qu'elle portent un jugement sur la politique islamique du régime.

Quant au nationalisme arabe version nassérienne, les confréries l'ont repris à leur compte, manifestant leur soutien en ce domaine lors des moments les plus critiques. Le chaykh Muhammad Mahmûd 'llwân, à peine installé dans ses fonctions de chef suprême des confréries soufies, renouvela publiquement son soutien à Nasser à la suite de l'agression tripartite contre le canal de Suez. En octobre 1959, le Conseil soufi publiait un communiqué à la nation arabe "pour sauver l'Irak de la barbarie ", à un moment où la guerre des ondes entre Nasser et Qâsim battait son plein. En avril 1967, un autre communiqué du Conseil soufi condamnait « les complots réactionnaires du roi Faysal d'Arabie et du chah d'Iran, du roi Husayn et de Bourguiba.» Au moment de la défaite de 1967, les confréries réaffirmèrent avec force leur soutien à Nasser. En décembre de cette année-là devait avoir lieu le plus grand cortège soufi jamais vu en soutien aux dirigeants politiques. La revue Al-lslâm wa-l-Tasawwuf se fit le héraut du nationalisme arabe, célébrant les relations entre l'égypte et les autres pays arabes. De même que pour les autres entreprises du régime, l'intervention militaire de l'Égypte au Yémen reçut ainsi l'approbation du Conseil soufi, qui fustigea en écho à la propagande officielle le " complot réactionnaire saoudien contre le peuple arabe yéménite ${ }^{36}$.»

L'intervention systématique du pouvoir nassérien dans les affaires soufies suscita une prolifération de confréries schismatiques qui refusaient de servir d'instrument politique. De plus, le pouvoir tentant de limiter le nombre de confréries officielles, les confréries sans statut commencèrent à prendre de l'importance, le fait que les confréries en étaient arrivées à être considérées comme un simple relais de la propagande officielle n'était pas un signe prometteur pour l'avenir, même si le soufisme put profiler, sous Nasser, de conditions favorables. Toujours florissante, la piété populaire trouvait, en effet, une occasion de réaffirmer sa prépondérance; la nature de l'allégeance à un chaykh soufi fait que, dans leur majorité, leurs adeptes ne 
s'émeuvent pas outre mesure du degré de compromission avec le pouvoir, l'essentiel pour eux étant ailleurs. Il faut également mentionner le fait que les confréries attirèrent, surtout à partir de 1952, ceux qui ne pouvaient s'adapter aux changements ou qui en étaient exclus. Peut-être était-ce là, de façon inconsciente, une manière d'opposition au nouveau régime. La manipulation des confréries par le pouvoir d'une façon aussi flagrante risquait, cependant, de porter gravement atteinte au prestige des chaykhs, particulièrement auprès des nouvelles classes sociales musulmanes qui avaient intégré la politique dans leurs préoccupations. Le clientélisme généralisé ne pouvait les séduire. Certes, on peut voir dans ce rapport utilitaire une bonne illustration du mépris de la politique que manifestent les chaykhs soufis. Mais on est obligé d'y reconnaître également la conséquence ultime de l'institutionnalisation du soufisme sous l'égide de l'État. En ce sens, le rapport cynique des chaykhs soufis à la politique, comme l'incapacité de répondre aux autres défis de la modernité, pouvaient bien illustrer le déclin évoqué par les chercheurs.

Malgré les obstacles nombreux auxquels elles sont confrontées, les confréries soufies continuent à attirer beaucoup plus de monde que ne pourraient le faire les courants de l'islam politique et les courants politiques modernes réunis. En effet, le soufisme confrérique illustre la force de la piété populaire avec tout ce qu'elle a d'autonome et d'irrécupérable. Il répond à un désir irrépressible de vie spirituelle, que d'aucuns croyaient dépassé avec l'affirmation d'un matérialisme moderne envahissant. Il offre l'appui du transcendant quand s'effondre l'espoir du social ou du politique. Certaines confréries soufies ont prouvé qu'il pouvait exister un soufisme moderne et qu'on pouvait même, en la matière, faire l'économie du réformisme. État, ulémas et chaykhs soufis, chacun s'occupant de sphères différentes, participent à un même ensemble cohérent qu'on pourrait appeler le consensus (ijma), cher au sunnisme. En contestant la légitimité de l'État et en utilisant la violence, les islamistes apparaissent comme ceux qui s'excluent d'un système politique d'inspiration sunnite, continuateur en bien des points de celui des Ottomans ${ }^{37}$.

\section{BIBLIOGRAPHIE}

- Arberry (A. J.), Introduction to the History of Sufism, Londres, 1943.

- Arberry (A. J.), Sufism, Londres, 1950.

- Achur (Sa'îd Abd al-Fattâh), Al-sayyid Ahmad al-Badawi. Chaykh wa Tarîqaa (Sayyid Ahmad alBadawi. Chaykh et confrérie), Le Caire, 1967.

- Al-Bichrl (Tariq), Al-musIimûm wa-l-aqbât fî itâr al-gamâ'a al-wataniyya (Les musulmans el les coptes dans la communauté nationale), Al-hay'a al-misriyya li-l-kitâb, le Caire, 1980.

- Dermenghem (Emile), Vies des saints musulmans, Sindbad, Paris, 1981.

- De Jong (Fred), The Sufi Orders in post-Ottoman Égypt. 1911-1981, Leiden, E. J. Brill.

- Defont (Octave), Coppolani (Xavier), Les confréries religieuses musulmanes, Alger, 1897. 
- Jomier (J.), Corbon (J.\}, « Le ramadan au Caire en 1956 », MIDEO, tome III, 1956, pp. 1-74.

- Massignon (Louis), La passion d'al-Hallâj, martyre mystique de l'islam, Seconde édition dirigée par H. Laoust et L. Gardet, Gallimard, Paris, 1975, 4 volumes.

- Mole (Marijan), Les mystiques musulmans, PUF, collection « Mythes et religions », Paris, 1965.

- Mustafa (Fârûq Ahmad), Al-binâ al-igtimâ'i li-l-tariqa al-Châdhiliyya fi Misr (La structure sociale de la Châdhiliyya en Égypte), Kulliyat al-âdâb fî Iskandariyya, al-hay'a al-misriyya al-'âmma li-lkitâb, Alexandrie, 1980.

- Nicholson (R. A.), Studies in Islamic Mysticism, Cambridge University Press, 1921.

\section{ANNEXES}

Annexe 1 : L'affaire al-Fâsi : une tentative de prise de contrôle d'une confrérie égyptienne par un affairiste saoudien

La duplicité de l'État dans son rapport aux confréries soufies, évoquée pour la Burhâniyya $^{38}$, s'est illustrée dans le cas de l'entreprise d'Al-Fâsi, autre affaire qui a défrayé la chronique soufie des dix dernières années. Mais cette fois-ci, elle a mis en jeu la plus ou moins grande capacité de l'État égyptien à défendre l'indépendance des confréries soufies et ses propres institutions soufies face aux pressions de l'argent.

En janvier 1986, chaykh Chams ad-Dîn al-Fasi, personnage célèbre de la scène activiste musulmane de Grande-Bretagne, à la fois affairiste richissime et grand pourfendeur de Salman Ruchdie, président du Conseil soufi mondial, un organisme basé à Londres, se rendit en visite au Caire. Considéré comme un organisme privé et de surcroît non égyptien, ce Conseil ne jouit d'aucun statut officiel en Égypte. Mais cette non reconnaissance n'a pas empêché de nombreux chaykhs soufis d'être représentés aux cérémonies en l'honneur d'al-Fâsî, ni les représentants de l'État de lui dérouler le tapis rouge. Al-Fasi s'offrit d'immenses placards publicitaires dans Al-Ahrâm tandis que les articles d'un journaliste défavorable au magnat saoudien étaient censurés par le rédacteur en chef du journal. Al-Fâsî promettait d'énormes sommes d'argent tous azimuts : pour la construction d'une nouvelle résidence d'étudiants à Al-Azhar, ou encore d'un nouveau siège à l'assemblée générale des chaykhs soufis. Tandis que le journal du Parti des libéraux Socialistes, Al-Ahrâr, se scandalisait des " pressions intolérables de l'argent qui menacent la liberté de la presse ${ }^{39}$ ", Chaykh Taftâzâni protestait officiellement, déclarant que l'argent ne pouvait être utilisé pour promouvoir telle ou telle confrérie ou tel ou tel chaykh par des campagnes publicitaires contraires à l'éthique soufie. Ce type de prosélytisme est d'ailleurs interdit par la loi, surtout lorsqu'il met en jeu l'indépendance d'une confrérie. Ce qui sembla rapidement le cas : la visite d'al-Fâsî préparait une véritable tentative de prise de contrôle de la Fâsiyya.

Confrérie reconnue officiellement en 1971 comme branche de la Châdhiliyya, la Fâsiyya était dirigée en Égypte par un wakil, représentant officiel de chaykh Muhammad Ibrâhîm al-Fâsi résidant à la Mecque. Cousin de ce dernier, chaykh Chams ad-Dîn al-Fâsî ne venait qu'en cinquième position dans l'ordre de la succession. Malgré tout, il exigea du Conseil supérieur soufi, fort du battage médiatique en sa faveur et de ses promesses financières, qu'il le nomme chaykh de la Fâsiyya, arguant du grand âge de son cousin. 
Le 16 janvier 1987, le refus du Conseil supérieur soufi de nommer al-Fâsî chaykh de la confrérie Fâsiyya était accompagné d'un appel aux responsables de l'État à lui interdire toute activité soufie en Égypte. La campagne médiatique en faveur du chaykh saoudien continuait, notamment orchestrée par Al-Liwâ' al-lslâmi, qui n'hésitait pas à présenter ce dernier comme un grand défenseur de l'islam face à l'Occident impie". Al-Fasi n'avait d'ailleurs jamais manqué de donner de lui-même cette image, se faisant attribuer le titre d'imam et exploitant sans retenue ses hauts faits d'armes à Hyde Park, Birmingham ou Bradford". En janvier 1988, un tribunal du Caire saisi par chaykh Taftâzânî exigeait des dédommagements d'al-Fâsî pour un encart dans Al-Liwâ' al-Islâmi où celui-ci accusait les confréries égyptiennes de pratiques non islamiques, et leurs chaykhs de s'enrichir aux dépens des pauvres. Le 29 novembre 1988, la Chambre administrative du Conseil d'État du Caire donnait raison au Conseil supérieur soufi d'interdire toute activité soufie d'al-Fâsî en Égypte, car « il menace, par son action, l'indépendance et l'organisation du soufisme en Égypte". » Toutefois, al-Fâsî ne s'avouera pas vaincu, faisant appel contre le jugement du tribunal, tandis que la polémique entre Tasawwuf Islâmî et Al-Liwấ' al-lslâmî devenait de plus en plus acerbe". Si les autorités avaient fini par se ranger du côté du Conseil supérieur soufi et de chaykh Taftâzânî, les hésitations et la bienveillance manifestée à al-Fâsî illustraient que pour certains secteurs de l'État, le rapport aux confréries soufies est avant tout considéré sous un angle utilitaire, surtout s'agissant d'éventuels apports financiers.

L'affrontement entre chaykh Taftâzânî et chaykh al-Fâsî illustrait aussi - le recours aux arguments islamistes des partisans d'al-Fâsi en témoigne - l'existence d'un antisoufisme au sein de l'État, expression de ce fondamentalisme rampant déjà évoqué.

Annexe II : Liste des confréries soufies égyptiennes officielles en 1990 Ordre Khalwatiyya

1) 'Azâziyya : sayyid 'Abd al-Rahîm Muhammad Ibrâhîm al-'Azazi est le chaykh de la confrérie. Fondée par une famille de la province de Charqiyya, se réclamant de la descendance de Sîdî 'Azâz al-Balâ'ihî, un saint de la lignée de Fatima. Reconnue au début du $\mathrm{Xx}^{\mathrm{e}}$ siècle, elle perdit ensuite son statut officiel pour de nombreuses années, ce qui est un fait exceptionnel. Rattachée à la Rifâ'iyya, la confrérie devint Khalwatiyya en 1903. Adresse: Charqiyya al-Qattâwîyya près de Abu Hammâd.

2) Bahwatiyya Khalwatiyya : sayyid Muhammad 'Umar Muhammad 'Abd âl-Mit'âl alBahwatî est le chaykh de la confrérie depuis août 1979. Adresse : Mansûra, Daqahliyya, direction de la sécurité.

3) Dâyfiyya Khalwatiyya : sayyid Ahmad Muhammad Amin al-Chawâribi est le chaykh de la confrérie. La Dayfiyya Khalwaliyya fut fondée par Muhammad Ismâ'îl Dayf (1854-1929), qui fut le premier à obtenir de chaykh al-Bakrî qu'il le reconnaisse comme chaykh d'une confrérie indépendante mais sans statut officiel. Ismâ'îl Al-Dayf, son fils Muhammad et ses descendants, sont enterrés à côté de Sîdî âl-Sammân dans la Cité des Morts (Qarâfa) près du mausolée de l'imam Châfi'i. Adresse : 29, rue Abu Bakr Siddîq $n^{0}$ 9 , Doqqî.

4) Ghunaymiyya Khalwatlyya : sayyid Abû-l-Wata al-Taftazâni, l'actuel chaykh suprême des confréries soufies, est le chaykh de la confrérie. Il a une chaire d'enseignement de la philosophie à l'Université du Caire. Confrérie reconnue officiellement en 1911, elle fut d'abord une ramification de la Rifâ'iyya. avant de s'en séparer vers 1910. S'est 
particulièrement répandue en Haute-Égypte. Le chaykh fondateur est enterré à Kafr alGhunaymi dans la Charqiyya où se trouve le siège de la confrérie.

5) Gûdiyya Khalwatiyya : sayyid 'Abd al-'Alîm Mustafâ al-'Askari est le chaykh de la confrérie depuis février 1981. Fondée en 1904. Adresse ; Qumash, Tansâ Banî Malû.

6) Gunaydiyya Khalwatiyya : chaykh Husayn al-Disûqî al-Gunaydî est le chaykh de la confrérie, depuis octobre 1979. C'est un uléma. Il fut élu plusieurs fois à l'Assemblée du Peuple. La confrérie fut fondée par chaykh Muhammad al-Gunaydî, enterré près de Banî Swit (le chaykh actuel est responsable du tombeau des Gunaydî). Adresse : Naziet al-Gunayd , Barîd al-Lîmûn . Al-Wâstâ.

7) Harâwiyya Hanafiyya Khalwatiyya : sayyid Amîn Ahmad Amîn al-Harâwî est le chaykh de la confrérie. Fondée par Sîdî Ibrâhîm al-Harâwî, enterré près de Zagazig. Adresse : Charqiyya, Huriyyat Rizna près de Zagazig.

8) 'llwâniyya Khalwatiyya : sayyid Mâlik Muhammad 'llwân est le chaykh de la confrérie. Tombeau du fondateur à Bilbays. Adresse : Shârqiyya, Bilbays.

9) Hâchimiyya Khalwatiyya : chaykh Mahmûd Ahmad Hâchim, recteur d'al-Azhar pour la Charqiyya, est le chaykh de la confrérie. Reconnue officiellement en juillet 1980. Adresse ; Charqiyya - Banî 'Amir près de Zagazig.

10) Khudayriyya Khalwatiyya : sayyid Muhammad Nûr al-Khudayrî est le chaykh de la confrérie. Se réclame de la descendance de Zubayr ibn al-'Awwâm, l'un des compagnons du Prophète. La confrérie fut l'un des quatre arbâb al-sagâgîd (titre honorifique des chaykhs de quatre confréries dont la position était similaire sous les Ottomans à celle de 'chaykh al-saggâda al-Bakriyya'), dont l'histoire remonte au XVe siècle. Dut se mettre sous l'autorité de la Khalwatiyya pour pouvoir être reconnue par chaykh alBakri, mais a perdu alors la majeure partie de ses membres. Ce n'est que dans les années 1940 que la confrérie réapparut. Son importance a de nouveau décliné à cause du désintérêt du chaykh actuel pour les tombeaux de ses ancêtres.

11) Marwâniyya Khalwatiyya : sayyid 'Umar Muhammad Yûsuf Marwân est le chaykh de la confrérie. Adresse : 2, rue al-Gabarûnî, Kafr al-Zayt.

12) Mughâziya Khalwaltyya : sayyid Muhammad 'Alî al-Mughâzî était le chaykh de la confrérie, le poste est actuellement vacant. Fondée en 1878 par Muhammad 'Amir alMughâzî, originaire du nord du Delta, la confrérie s'est développée autour d'un mausolée à Al-Kûm Al-Tawil. Elle fut, au début du xxe siècle, avec la Hâmidiyya, parmi les confréries les plus dynamiques, à un moment où la plupart des autres étaient sur le déclin. Adresse : Sîdi Ghâzî - Kafr ad-Dawâr - Buhayra.

13) Misallimiyya Khalwatiyya : sayyid Kamâl Muhammad aJ-Sayyid Hasan al-Misallimî est le chaykh de la confrérie depuis octobre 1981. Fondée au milieu du Xllle siècle par un chaykh de Baghdad et reconnue par chaykh al-Bakri comme confrérie officielle. Le tombeau de Salim Abu Misallim al-Hamdânî al-Saghîr est à al-Sawwâ, à l'est de Zagazig, et c'est l'un des mausolées les plus célèbres du Delta oriental. Adresse : Charqiyya, Khalwa Abu Musallim Barid al-Sahwa. Une importante zâwiya dépendant de la Misallimiyya se trouve à Gîza.

14) Muslihiyya Khalwatiyya : sayyid Ahmad Fathî 'Abd al-Salâm aI-Muslihî est le chaykh de la confrérie. Adresse : Menûfiyya, Shibin al-Kom, Mustashfâ al-himâyât. 
15) Qasabiyya Khalwatiyya : sayyid Ahmad 'Abd al-Hâdi al-Qasabi, ancien ministre et gouverneur de la Gharbiyya, est le chaykh de la confrérie. Confrérie officiellement reconnue en mai 1980. Adresse : Tanta, 'Imârat ai-Gama'iyya ai-Yûnâniyya, rue chaykh Yûsuf Karam.

16) Qâyâtiyya : sayyid Kamâl 'Abd al-Gawâd al-Qâyâtî, qui fut membre de Maglis alUmma en 1960, est le chaykh de la confrérie. Fondée par 'Abd al-Latif al-Qayâti (mort en 1842). L'une des confréries les plus actives dans l'insurrection de 'Urâbî. Pour cette raison, son chaykh fut exilé à Beyrouth par les Anglais entre 1882 et 1888. Reconnue officiellement en 1960. Le centre de la confrérie est le village d'al-Qayât, près de Maghâgha.

17) Sammâniyya Khalwatiyya : sayyid 'Abd al-'Aziz Muhammad Ibrâhîm al-Gamal est le chaykh de la confrérie. Fondée par chaykh Muhammad 'Abd al-Karîm al-Sammân (1717-1775), un disciple du chaykh syrien al-Bakrî. Aujourd'hui, principalement représentée au Soudan. Cette confrérie y a soutenu les Mahdistes. La tombe et la mosquée de chaykh Hamad al-Sammân (neveu du fondateur de la confrérie) sont dans la Cité des Morts (Qarâfa) près du mausolée de l'imâm Châfi'i. 'Confrérie reconnue officiellement en 1906. Adresse : 43, rue Hôch Qadam, Darb al-Ahmar, le Caire.

18) Sâwiyya Khalwatiyya : le chaykh actuel est, depuis septembre 1985, sayyid Ahmad al-Sayyid Ahmad 'Ali al-Sâwî, qui est un important uléma d'al-Azhar, diplômé de la faculté de théologie d'al-Azhar, et qui travaille aujourd'hui au ministère des Waqf. Sayyid Ahmad al-Sayyid Ahmad al-Sâwî (1764-1825), originaire de La Mecque, est le chaykh fondateur de la confrérie. C'est la plus importante des branches issues de la Khalwatiyya. Elle s'est répandue en Égypte, au Yémen et au Hidjâz, Reconnue officiellement en janvier 1979. Adresse : Fayyûm, 'Imârat al-Awqâf.

19) Chabrâwiyya Khalwatiyya : sayyid Mustafâ 'Abd al-Khâliq al-Chabrâwi esl le chaykh de la confrérie. C'est un uléma important, ancien juriste au ministère des Waqfs, et membre du Conseil soufi depuis 1952. Confrérie fondée au XIXe siècle par Sîdî 'Umar Ga'far al-Chabrâwî. Les chaykhs de cette confrérie se réclament de la descendance de 'Umar. Mosquée et tombeau de la confrérie construits sous Sadate, à Darrâsa. Adresse : 100, rue al-Sûdân - Madînat al-Awqâf -face au tribunal d'Imbâba.

Les plus importantes des confréries Khalwatiyya non reconnues:

1) Buyyûtiyya Khalwatiyya : sayyid 'Umar Muhammad 'Abd al-Mit'âl est le chaykh de la confrérie.

2) 'Imrâniyya : fondée en 1850 par Ibrâhîm al-Shâlqânî al-'Imrânî, enterré à Bardûna alAshrâf, près de Banî Mazâr, qui devint le centre de la confrérie.

3) 'Imrâniyya Qubaysiyya Khalwatiyya : sayyid Ahmad al-Sayyid Abu 'Imrân al-Qubaysî est le chaykh de la confrérie. A demandé à être reconnue officiellement en août 1980, sans l'obtenir, le nombre des confréries étant alors jugé suffisant.

Ordre Ahmadiyya

1) Bayyûmiyya Ahmadiyya : sayyid Hâmid Ahmad Fadı est le chaykh de la confrérie. Fondée par chaykh 'Alî al-Bayyûmî (mort en 1769), enterré dans le quartier d'alHusayn. Après la disparition du fondateur, de nombreuses dissensions sont apparues dans le choix des successeurs. Plusieurs chaykhs concurrents, dont l'un soutenu par le Cheikh al-Azhar, ont souvent été à la tête de cette confrérie au cours du XVIIIe siècle. A 
toujours été respectueuse de l'autorité de chaykh al-Bakri. Le chaykh de la Bayyûmiyya fut membre du Conseil soufi de 1903. Le centre de la confrérie est à Bâb Cha'riyya, à Mîdân al-Gaysh où réside le chaykh. En 1982, la Bayyûmiyya avait 250 nâ'ib, 150 khalîfa al-khulafâ et 4000 khalîfa. Adresse : Rue Amir al-Guyûsh, Hâral Kaff al-Môz 6, Gamaliyya.

2) Farghaliyya Ahmadiyya ; sayyid Ahmad Sabri 'Abd al-Rahmân al-Farghalî est le chaykh de la confrérie. Il est membre du Conseil supérieur des confréries soufies depuis plus de dix ans. Directeur des examens pour al-Azhar dans la province de Qalyûbiyya, il enseigne aussi à al-Azhar l'exégèse coranique et les commentaires de hadith. Les chaykhs de cette confrérie sont les protecteurs du célèbre mawlid d'Abû Tîj, là où est enterré le fondateur de leur confrérie, chaykh Sultan al-Sa'îd al-Farghalî. La famille dirigeante de la confrérie fut également responsable du tombeau de Sultan Abû-1-'Alâ à Bûlâq. En février 1983, la confrérie avait 100 nâ'ib et 2000 murîd en Égypte. Est aussi implantée en Algérie. Siège à Benhâ, 27 rue 'Abd al-'Azîz.

3) Ga'fariyya Ahmadiyya Muhammadiyya : sayyid 'Abd al-Ghani Sâlih al-Ga'fari est le chaykh de la confrérie. Officiellement reconnue le 25 novembre 1986. Bien implantée à Assouan. Siège à la mosquée al-Ga'fari place al-Khâlidayn à Darrâsa.

4) Gawhariyya Ahmadiyya : sayyid Husayn Abû'l-Hasan al-Gawharî est le chaykh de la confrérie. Il est l'imam de la mosquée al-Gawharî à Bilqâs et responsable des impôts pour la ville. Fondée par chaykh 'Abd al-Wahhâb al-Gawharî au XVIle siècle. Confrérie d'origine Châdhili. La mosquée de la famille al-Gawharî est rue Gawhar al-Qâ'id à Gamâliyya. Adresse : Bilqâs, Daqahiiyya.

5) Habîbiyya Ahmadiyya : chaykh Munammad 'Abd al-Bâqî al-Habîbî est le chaykh de la confrérie. D'origine Rifâ'iyya, devint une confrérie indépendante en 1888.

6) Halabiyya Ahmadiyya : chaykh Muhammad Chafîq al-Gunaydî esl le chaykh de la confrérie. Fondée au XVe siècle par Ahmad al-Halabî, et reconnue comme l'une des quatre bayt saghîr (bayt kabîr et bayt saghîr Ahmadiyya : groupes des principales confréries de la Ahmadiyya à partir du XVe siècle) de la confrérie. Le chaykh faisait partie de la procession du mahmal. Figure dans la liste officielle des confréries de 1905. Adresse : 5 , rue Skrâbiyya, Masr al-Gadida.

7) Humûdiyya Ahmadiyya : sayyid Ibrâhîm Muhammad Hamûda al-Maghrabî en est le fondateur. Reconnue sous le règne de Mehmet Ali. Le chaykh faisait partie de la procession du mahmal. Adresse : Gharbiyya - Zeftî.

8) Imbâbiyya Ahmadiyya : sayyid 'Alî 'Abd al-Salâm Salmân est le chaykh de la confrérie. Fondée par chaykh Ismâ'îl al-Imbâbî au XVe siècle. L'une des cinq bayt kabîr de la Ahmadiyya. Faisait partie de la procession du mahmal. Conflits et concurrence entre Imbâbiyya et Kannâsiyya. La gestion du tombeau d'Ismâ'îl al-Imbâbî a longtemps échappé au chaykh de la confrérie, car il était entre les mains de la famille Nuwaytû, qui dirige la Kannâsiyya. Un chaykh Nuwaytû a aussi dirigé, au début du siècle, pendant dix années, les deux confréries, ce qui est exceptionnel. Adresse : Warâq al-'Arab Imbâba.

9) Kannâslyya Ahmadiyya : sayyid Muhammad Salâma Nuwaytû est le chaykh de la confrérie. Il est aussi directeur de la Banque sociale Nâsîr depuis juin 1982 (il s'agit d'une grande banque islamique pour le développement social, qui consent des prêts sans intérêts - mariage, maladie, décès ou catastrophe naturelle) et secrétaire financier du Conseil supérieur soufi dont il est membre depuis plus de dix ans. Fondé par chaykh 
Muhammad al-Kannâsî (chargé de l'entretien du tombeau de chaykh al-Badawi), ce fut l'une des cinq bayt kabîr de la Ahmadiyya. Conflits entre Kannasiyya et Imbâbiyya dès lors que les chaykhs Nuwaytû en prirent le contrôle. Faisait partie de la procession du mahmal. Chaykh 'Ali Nuwaytû fut membre du Conseil soufi de 1903. Adresse : 3, rue Muhammad Yûsuf Salîm, Masr al-Gadîda.

10\} Kenâniyya Ahmadiyya : sayyid al-Charif Hasan al-Kenâni est le chaykh de la confrérie.

11) Manâfiyya Ahmadiyya : chaykh 'Abd Allah 'Ali Fû́âd al-Minûfi est le chaykh de la confrérie. Fondée par Ramadan al-Ach'ath al-Minûfî et 'Abdallâh al-Minûfi (mort en 1348). L'une des cinq bayt kabîr de la Ahmadiyya. Faisait partie de la procession du mahmal. Adresse : 2, Hâra Mustafâ Yahyâ - rue Ahmad Pacha Kamâl - Chubrâ.

12) Marâzlqa Ahmadiyya : sayyid Ahmad Muhammad Chams al-Dîn, qui est avocat, est le chaykh de la confrérie depuis juillet 1979 et le chef des sayyids Ahmadiyya Marâziqa. Il est membre du Conseil soufi depuis plus de dix ans. Il est aussi secrétaire du conseil d'administration de la mosquée de Husayn. Egalement membre du Parti national démocrate (section de la sécurité des affaires religieuses). L'une des cinq bayt kabîr de la Ahmadiyya, fondée par Marzûq al-Yamanî. Le chaykh de la Marâziqa avait le privilège traditionnel de guider le chameau portant le mahmal de Dâr al-Kiswa à la place de Mehmet Ali. Fut respectueuse de l'autorité de chaykh al-Bakri. Conflits de succession au début du Xx $x^{e}$ siècle. Mosquée de Sidî Marzûq al-Ahmadî à Qasr al-Shawq, Darb alTablawî, où se trouve également le siège de la confrérie, à Gamâliyya.

13) Salâmiyya Ahmadiyya : sayyid Muhammad Mustafâ Safwat est le chaykh de la confrérie. L'une des cinq bayt kabîr de la Ahmadiyya, fondée par 'Alî al-Gawharî au XVe siècle. Mais elle a longtemps été incorporée à.la famille des Marzûqiyya. Faisait partie de la procession du mahmal. Adresse : 9, rue Miqyâs al-Rôda.

14) Chinnâwiyya Ahmadiyya : sayyid Hasan Muhammad Sa'îd al-Chinnâwi est le chaykh de la confrérie. Membre du Conseil soufi depuis plus de dix ans, en même temps que directeur de la Mission (da'wa) d'al-Azhar dans la province de Gharbiyya. C'est un uléma important, qui fut inspecteur général des waqf de la Gharbiyya. Confrérie fondée au XVIe siècle par Muhammad al-Chinnâwî (mort en 1526). L'une des quatre bayt saghîr de la Ahmadiyya. La famille Chinnâwiyya a longtemps contrôlé le mausolée d'Ahmad Badawi à Tanta: Son centre est à Mahallat Rûh, au nord de Tanta. Celle confrérie prit une énorme importance à la fin du XVIII ${ }^{e}$ siècle. A eu les faveurs des pachas ottomans au moment de la campagne d'Égypte de Bonaparte. Comme la confrérie avait son siège dans la province de Minûfiyya et non au Caire, elle n'aurait pas du être reconnue. Un arrangement exceptionnel intervint puisque 'Umar af-Chinnâwî, un autre membre de la famille résidant au Caire. Fut officiellement reconnu comme chaykh de la confrérie en 1870. Une rivalité s'installa, dès lors, entre le chaykh résidant au Caire et la famille résidant dans le delta, avec parfois deux chaykhs à la tête de la confrérie. Jusqu'à la promulgation de la loi de 1903 qui imposa un seul chaykh par confrérie. Adresse : 14, rue al-Khawârizm, rue 'Uthmân Muhammad, Tanta,

15) Chu'ayblyya Ahmadiyya : sayyid Muhammad Hasan al-Chu'aybi esl le chaykh de la confrérie. Fondée au XVIII ${ }^{e}$ siècle par Ibrâhîm al-Chu'aybî (mort en 1796). Faisait partie de la procession du mahmal. Répandue en Égypte et à TIemcen en Algérie. Adresse : 17, Darbat-Farâkha, Qasr al-Shawq, Gamâliyya- 
16) Sutûhlyya Ahmadiyya : sayyid 'Abd al-Samî' Muhammad Mahmûd al-Sutûhî est le chaykh de la confrérie. C'est le fils de l'ancien chef suprême des confréries soufies. Fondée par Muhammad al-Sutûhî (enterré dans la province de Minûfiyya) au XVlle siècle. L'une des quatre bayt saghîr (2) de la Ahmadiyya. Confrérie provinciale, la Sutûhiyya fit de grands efforts pour s'implanter au Caire, ce qu'elle réussit à la fin du XVIII' ${ }^{\mathrm{e}}$ siècle, en se taisant octroyer la mosquée et le tombeau de l'un de ses saints. Farag al-Sutûhî (aujourd'hui mosquée al-Hifnî). Une fois implantée au Caire avec un chaykh y résidant, la confrérie fut reconnue par chaykh al-Bakri. Adresse : 50, rue 77, Ma'âdî.

17) Tasqiyâniyya Ahmadiyya : sayyid Ibrâhîm Ahmad Ibrâhîm al-Tasqiyâni esl le chaykh de la confrérie. C'est une ancienne confrérie qui fut fondée au Xllle siècle par 'Abdallâh af-Tasqiyâni. Faisait partie de la procession du mahmal. Adresse ; 15, rueManchiyat alGamal, Zâwiya Hamrâ', le Caire.

18) Zâhidiyya Ahmadiyya : sayyid Hasan Yûsuf Khalil al-Zâhidî est le chaykh de la confrérie. Le fondateur de la confrérie est Sîdî Ahmad Sulaymân al-Zâhidi (mort en 1416), qui revendiquait une descendance de Hasan, donc qui était un charîf 'alawî. Son père avait émigré du Maroc à Qenâ. L'une des quatre bayt saghir de la Ahmadiyya. Faisait partie de la procession du mahmal. Confrérie provinciale, elle ne fut pas active au Caire avant le milieu du XIx ${ }^{\mathrm{e}}$ siècle, au moment où elle obtint le contrôle du mausolée d'Ahmad al-Zâhid à Sûq af-Zalat (Bâb Cha'riyya). A partir de 1870, son importance grandit, mais elle déclina ensuite de façon irrémédiable. Adresse : Minûfiyya, Centre Ashmûn, Centrîs.

Les plus importantes des contréries Ahmadiyya non reconnues :

1) Akbariyya Ahmadiyya;

2) 'Arabiyya Ahmadiyya ;

3) Ghazâliyya Ahmadiyya ;

4) Hâchimiyya Khalwatiyya Ahmadiyya : sayyid Muhammad Mahmûd Ahmad Hâshim, recteur de la faculté de théologie de Zagazig, est le chaykh de la confrérie.

5) Khurâchiyya Ahmadiyya : tombeau du chaykh fondateur près de Manfalût.

6) Mahmûdlyya Ahmadiyya : sayyid Ibrâhîm Muhammad al-Maghrabi est le chaykh de la confrérie depuis août 1990.

7) Manâwiyya Ahmadiyya : confrérie centrée autour de Miniyâ

8) Charqâwiyya Ahmadiyya : confrérie fondée par chaykh al-Charqâwi.

Ordre Burhâmiyya

1) Burhâmiyya ; sayyid Muhammad 'Ali 'Achûr est le chaykh de la confrérie-mère. Née au début du XIVe siècle. A connu une forme d'autorité centrale en Égypte avant les Ottomans. La famille 'Achûr dirige la confrérie depuis le sultan mamelouk Qâytbây qui lui a attribué cette fonction qu'elle a perpétuée jusqu'à nos jours, fait exceptionnel. Toutefois, l'autorité de la confrérie est centrée sur le Caire, tandis qu'en province, elle a été devancée par la Charnûbiyya et la Chahâwiyya. Faisait partie de la procession du mahmal. Adressa : 16, Darb Râchîd, Qasr al-Shawq, Gamâliyya.

2) Burhâmiyya Fâridiyya ; 
3) Mugâhidiyya Burhâmiyya : sayyid 'Abd al-Qâdir Ahmad Mugâhid est le chaykh de la confrérie. Cette confrérie semble aujourd'hui la plus présente au mawlid de sayyid Ibrâhîm ad-Disûqî : une grande tente à ses couleurs jouxte la sortie ouest de la mosquée et le chaykh de la confrérie, en habit d'apparat et sur un cheval blanc, conduit la procession soufie dans les rues de la ville. Adresse : Tanta, 'Imârat al-Inchâ' wa-l-ta'mîr, tariq al-sarî qahhâfa.

4) Sa'îdiyya Charnûbiyya Burhâmiyya : sayyid Ibrâhîm Muhammad Sa'îd al-Charnûbî en est le fondateur. Nommée d'après Ahmad 'Arab ibn 'Uthmân al-Charnûbî (1524-1585). Le village de Charnûb se trouve dans la province de Buhayra. L'une des deux branches de la Burhâmiyya dans le Delta, qui n'eut jamais le contrôle du mausolée de Disûq. N'a aucun lien avec la confrérie Burhâmiyya-mère (famille 'Achûr). Fut reconnue par chaykh al-Bakri dès 1870. A une autorité centrale faible. Adresse : Qalayn hissat alghani.

5\} Chahâwiyya Burhâmiyya : sayyid 'Abd al-Magîd .Abû-l-Magd al-Chahâwî est le chaykh de-la confrérie depuis avril 1984. Fondée par Muhammad al-Chahâwî (1469-1542), dont le tombeau se trouve à Nimrat al-Basal, près de Mahalla Kubrâ, elle est, avec la Charnûbiyya, l'autre branche de la Burhâmiyya dans le delta. Comme la Charnûbiyya, elle ne contrôla jamais le mausolée de Disûq. Semble n'avoir eu aucun lien avec la Burhâmiyya-mère dirigée par la famille 'Achûr. Fut reconnue par chaykh al-Bakri dès 1870. A une autorité centrale faible. Adresse : 8, Rue Madrasat Walî al-'Ahd. 'Abbâsiyya.

6) Charnûbiyya Burhâmiyya : sayyid Muhammad 'Abd al-Magid al-Charnûbî est le chaykh de la confrérie. Adresse : 22, rue Nabî Daniel, Alexandrie.

Les plus importantes des confréries Burhâmiyya affiliées à une confrérie officielle :

- Bayt al-sâda al-Burhâniyya al-Disûqiyya al-Châdhiliyya : sayyid Ibrâhîm Muhammad 'Uthmân 'Abduh al-Burhânî est le chaykh de la confrérie. Fondée au Soudan et dirigée de Khartoum par chaykh Muhammad 'Uthmân 'Abduh al-Disûqi al-Burhânî dans les années cinquante, la confrérie ne compta jamais beaucoup d'adeptes au Soudan. Se réclame de deux affiliations, châdhilie et burhâmie, mais l'impact de la Burhâmiyya est la plus importante. Cette confrérie est issue de la Burhâmiyya-mère dirigée par chaykh 'Ali 'Achûr. Actuellement l'une des confréries les plus importantes d'Égypte, elle fut interdite dans les années 1970 pour avoir propagé des théories 'hérétiques', avant d'être de nouveau autorisée en 1988. (cf. Maghreb-Machrek op. cit. note 37). Son chaykh actuel, Ibrâhim Muhammad 'Uthmân 'Abduh al-Burhânî, le fils du fondateur de l'ordre, s'est vu retirer temporairement ses titres par le Conseil supérieur des confréries soufies en août 1990, à la suite d'un conflit avec son nấ'ib en Égypte, sayyid Hamdî al-Gindi, relançant ainsi les hostilités avec les autorilés soufies égyptiennes. Adresse : place al-Husayn face à Bâb al-Akhdar.

Ordre Châdhiliyya

1) 'Afífiyya Châdhiiiyya : sayyid Muhammad Diyâ' ad-Dîn 'Abd aJ-Bâqi al-'Afîfî est le chaykh de la confrérie. Comptable, il fut conseiller financier à l'ambassade du Yémen, puis directeur administratif de la compagnie d'assurances 'al-Charq'. Confrérie d'origine égyptienne. Adresse : 3, rue al-Guhaynî. Doqqî.

2) 'Afîfiyya Hâshimiyya Châdhitiyya : sayyid 'Arîfî Ahmad al-Sâkit est le chaykh de la confrérie. Egalement chaykh de la mosquée de Sayyida 'A'icha, c'est un uléma 
imponant. Il lut directeurs des waqf du Caire. La 'Afîliyya fut fondée en 1758 par 'Abd al-Wahhâb al-'Atifî (mort en 1758). dont le tombeau est un peu avant la mosquée de Qâytbây dans la Cité des Morts-nord. Compta de nombreux ulémas dans ses rangs, mais fut condamnée par Gabartî pour ses pratiques de dhikr jugées non conformes à la charî’a. Fut respectueuse de l'autorité de chaykh al-Bakrî. Adresse : 15, rue Qâsim Amîn, Hadâ'iq'al-Qubba, Le Caire.

3) 'Arûsiyya Châdhiliyya : sayyid 'Alî Fikrî Mansûr Karîm est le chaykh de la confrérie depuis février 1981. Fondée par Ahmad ibn 'Arûs (mort en 1463). Figure sur la liste officielle des confréries de 1872. Une lutte pour la direction de la confrérie a donné naissance à la Salâmiyya en 1890. Adresse : 18, rue al-Salhiyya, Al-Husayn.

4) 'Azamiyya Châdhiliyya : sayyid 'Izz al-Din Mâdî Abû-l-'Azâ'im, qui est avocat à la cour de cassation, et directeur du service contentieux de la société pétrolière Misr est le chaykh de la confrérie. Fondée au Soudan en 1915 par un chaykh égyptien, sayyid Muhammad Mâdî Abû'l-'Azâ'im, qui joua un rôle important dans le débat sur le califat et dans la lutte anti-britannique. Cette confrérie s'imposa rapidement comme le porteparole d'un énergique soufisme réformiste. L'une des plus importantes confréries en Égypte. Publie la revue mensuelle Al-lslâm Watan (L'islam est une patrie). Adresse : 114, rue Maglis al-Châ'b.

5) Fâsiyya Châdhiliyya (Burhâmiyya) : sayyid Ahmad Muhammad Ahmad Hasan est le wakîl de la confrérie en Égypte depuis 1985. Il représente le chaykh actuel de la confrérie, chaykh Muhammad Ibrâhîm al-Fâsî, qui réside à La Mecque. Confrérie fondée par Muhammad al-Fâsî (mort en 1872), originaire du Maroc, pèlerin à la Mecque installé dans les environs de Zagazig, puis réorganisée par chaykh 'Abd al-Rahmân alMakkî al-Fâsî. Les chaykhs de la Fâsiyya ont condamné le dhikr comme contraire à l'islam. Confrérie récente reconnue de façon officielle en Égypte en 1971. La confrérie a connu divers schismes. Adresse : 6, rue al-Ma'mûn. Madinat al-Awqâf, Imbâba.

6) Faydiyya Châdhiliyya : sayyid Ahmad Muhammad Amin al-Châwâribî est le chaykh de la confrérie. Sayyid Mahmûd Mahmûd Abû-l-Fayd al-Minûfi (mort eh 1971) en est le fondateur. Officiellement reconnue en 1950. Adresse : Le Caire. Al-Wâ'ili al-Kabîr, Hadâ'iq al-Qubba. ..

7) Gawhariyya Châdhiliyya : sayyid 'Abd al-Rahîm Muhammad al-Gawharî est le chaykh de la confrérie depuis juillet 1979. Il est membre du Conseil soufi depuis plus de dix ans. Il est aussi chaykh du tombeau de son ancêtre Sîdî Abû'l-Ma'âlî al-Gawharî, à la mosquée al-Gawhari à Gamaliyya. La famille al-Gawharî a obtenu la direction de la Châdhiliyya en Égypte sous le règne de Mehmet Ali. Adresse ; 4, rue an-Nabaweyya, AL-'Abbâsiyya.

8) Hâmidiyya Châdhiliyya : sayyid 'Abd al-Mun'im Mahmûd al-Gundi est le nâ'ib actuel de la confrérie ; Sîdî Ibrâhîm Salâma al-Râdî a conservé lé titre de chaykh, bien qu'il soit mort, résultat d'un compromis entre la famille al-Râdî et la nấib. La Hâmidiyya est une branche moderne de la Châdhiliyya, à l'organisation rationalisée. C'est la plus importante des confréries Châdhiliyya. Son siège est près du club de Zamâlik, à Mohandessin, rue al-Higâz. Il y a là la mosquée Hâmidiyya Châdhiliyya, qui renferme les tombeaux de Sîdî Hasan Salâma al-Râdî et de son fils Sîdî Ibrâhîm Salâma al-Râdî (mort en 1976), ainsi qu'un important complexe moderne de services sociaux et d'éducation. 
9) Handûshiyya Châdhiliyya : sayyid Hasan Muhammad Harâzim est le chaykh de la confrérie. Fondée par 'Alî ibn Handûch (mort en 1716), enterré au Maroc près de Meknès. Connue pour ses pratiques extatiques. Les adeptes sa frappaient le crâne avec des tiges de fer, avalaient des charbons ardents, des serpents et des morceaux de verre, jusqu'à l'interdiction de cette pratique par la circulaire de 1881 .

10) Hâchimiyya Madaniyya Châdhiliyya : sayyid Mustafâ Muhammad al-Tâhir al-Sâfî alHâchimî est le chaykh de la confrérie depuis août 1985. Fondée par Muhammad alHâchimi (mort en 1911), un khalîfa de la Madaniyya qui réussit à faire reconnaître sa propre confrérie par chaykh al-Bakrî, après avoir fait du prosélytisme pour son propre compte dans le nord du delta. Adresse : 104, rue al-Muhâfaza, AL-'Attarîn. Alexandrie.

11) Hisâfyya Châdhiliyya : sayyid Muhammad Abû-l-Asrâr al-Hisâfî est le chaykh de la confrérie. Fondée par Muhammad Hasanayn al-Hisâfî (1848-1910), se développa comme une réémergence de la 'Inâniyya. Hasan al-Banna en fut membre. Reconnue officiellement le 21 février 1989. A, depuis novembre 1988, une mosquée à Damanhûr.

12) Idrisiyya Châdhiliyya : le poste de chaykh de la confrérie est actuellement vacant. Son fondateur est chaykh Sâlih al-Ga'farî al-Idrisî. Reconnue par chaykh al-Bakri en 1870. A une mosquée à Gamâliyya.

13) Madaniyya Châdhiliyya : confrérie issue de la Fâsiyya, fondée par Muhammad Hasan ibn Hamza Zafîr al-Madanî (mort en 1846). Sayyid Muhammad Yûsuf aJ-Marzûqî est le chaykh de la confrérie depuis mars 1980. Il est contrôleur général de la banque Misr. Son père, le chaykh précédent, sayyid Yûsuf al-Marzûqî, était un uléma qui occupa la fonction de directeur de la compagnie égyptienne d'égrenage du coton. Officiellement reconnue en 1906. La Hâchimiyya en est issue, avec à sa tête un khalîfa madani du delta qui réussit à faire reconnaître sa propre confrérie par chaykh al-Bakri. A de nombreuses zâwiyas, ainsi qu'un centre de formation. Siège de la confrérie à al-Darrâsa et à al-Gawdriyya. Adresse : 24, rue aJ-Miqyâs, Rôda.

14) Muhammadiyya Châdhiliyya : sayyid Muhammad Zaki Ibrâhîm al-Khalil est le fondateur et l'actuel chaykh de la confrérie. Cette confrérie fut reconnue officiellement le 3 septembre 1951. Son siège est à la mosquée de la confrérie, rue Sultan Ahmad, voie parallèle à la rue Salâh Sâlim, dans la Cité des Morts près du mausolée de Qâytbây. Dirige une importante association de bienfaisance soufie, la 'Achîra Muhammadiyya (la Famille muhammadienne), qui publie le mensuel AL-Musiim et dont le siège est rue Port-Saïd, près du croisement avec la rue al-Azhar, ancienne Mosquée des Filles d'alAzhar.

15) Qâsimiyya Châdhiliyya : sayyid Samîr 'Abd al-Hamîd 'Abd al-Magîd al-Barmûnî est le chaykh de la confrérie. Introduite en Égypte dans la première moitié du XVIII ${ }^{\mathrm{e}}$ siècle. 'Alî al-Habbâk (mort en 1780) en est le fondateur. Son chaykh fut membre du Conseil soufi de 1903. Le dhikr de cette confrérie était caractérisé par des pratiques spectaculaires (absorption de verre, de charbons incandescents et de serpents) jusqu'à l'interdiction de ces pratiques en 1881.

16) Qâwuqagiyya Châdhiliyya : sayyid Muhammad Rida Abû-l-Fath al-Qâwaqagiyya est le chaykh de la confrérie. Fondée par Muhammad ibn Khalîl aJ-Qâwuqagî (Abû-lMahâsin) (1809-1887). Centrée autour de Tanta et de Damiette. Reconnue par chaykh alBakri au début du $\mathrm{xx}^{\mathrm{e}}$ siècle. A donné naissance à la Salâmiyya et se revendique d'une 
généalogie qui interfère avec celle de la Fâsiyya. Adresse : 110 rue al-Higâz, Masr alGadîda.

17) Salâmiyya Châdhiliyya : sayyid Muhammad 'Abd al-Salâm Taha Machina est le chaykh de la confrérie. Anciennement connue sous le nom de 'Arûsiyya, mais lors de sa reconnaissance officielle en 1892, prit ce nouveau nom. Ne se manifesta réellement qu'après la Seconde guerre mondiale. Centrée autour d'Alexandrie. Adresse : 22, rue alSibâq, Darrasa.

18) Wafâ'iyya Châdhiliyya ou al-Sâda al-Wafâ'iyya : chaykh Muhammad Hasan al-'Arûsî est le chaykh de la confrérie. Fondée par Mahmûd 'Afîf al-Din al-Wafâ'i (mort en 1900). Se veut l'héritière de la Wafầiyya, l'une des quatre arbâb al-sagâgîd dont l'histoire remonte au XVe siècle. Fait remonter à 'Alî la généalogie'de ses chaykhs. Nombreuses interférencas avec la Fâsiyya. Adresse : 13, rue chaykh al-'Arâsa, Bâb Châ'riyya, le Caire.

La plus importante des confréries Châdhiliyya non reconnues ;

'Isawiyya : le chaykh de la confrérie est Hasan 'Isawî ' Ismat depuis février 1981. Fondée par le Marocain Muhammad ibn 'Isa. Reconnue dès 1848. Pratiquait des automutilations lors des séances de dhikr, organisant des marches sur des charbons ardents. Celte confrérie aujourd'hui non reconnue est officiellement affiliée à la Gawhariyya Chadhiliyya. Implantée au Caire, où elle participe aux mawlid.

Ordre Rifâ'iyya

Cet ordre devint si indulgent envers l'utilisation de la musique qu'on finit par appeler ses adeptes les derviches hurleurs. PendanI qu'il récitaient le dhikr en cercle en se tenant par les épaules, ils faisaient des mouvements du corps d'arrière en avant de plus en plus rapides avant de tomber en extase sur un parterre parsemé de couteaux ou de serpents, D'autres dansaient les yeux fermés sur un mur, les bras ouverts, ou encore avalaient du verre.

1) Rifâ'iyya : sayyid Mahmûd Ahmad Kâmil Yasin Al-Rifầi est le chaykh de la confrérie. Régulièrement réélu, depuis 1945, au Conseil soufi, dont il est le vice-président. Il est aussi le président du conseil d'administration de la compagnie de produits pharmaceutiques Suisse Pharma. En janvier 1989, il est également élu président du conseil d'administration du club de football 'Tarsâna. Madame Fayda Kâmil, l'épouse du chaykh, est membre du Parlement. En janvier 1983, sayyid Mahmûd Yâsîn aJ-Rifâ'î a fait don de soixante mille livres égyptiennes pour soutenir les instituts d'al-Azhar. Cette donation ira en particulier à l'institut du défunt Ahmad Kâmil Yâsîn, dans le quartier al-Khalifa près de la citadelle. En mai 1984, inauguration de l'institut soufi Ahmad alRifâ'i. La confrérie fut l'un des quatre aqtâb (LES quatre pôles ou aqtâb arba'a: Ahmadiyya, Burhâmiyya, Rifấ'iyya, Qâdiriyya, tous ordres qui montrent une continuité en Égypte depuis l'époque mamelouke.) A toujours eu une structure très lâche. Pratiquait des mutilations lors de ses séances de dhikr et des pratiques interdites en 1881. Demeura respectueuse de l'autorité de chaykh al-Bakrî. Les porteurs d'eau appartenaient surtout à la Rifâ'iyya. Tekkiyé de la Rifâ'iyya à Bûlâq (aujourd'hui école primaire). Dans la Cité des Morts-nord, tombeau appartenant à la Rifâ'iyya, surmontée d'un dôme, datant du milieu du XVIe siècle. La mosquée al-Rifầ'i, pastiche du règne d'Ismâ'îl, achevée en 1912, abrite les tombeaux de Fû'âd et de Fârûq ainsi que celui du chah d'Iran. Adresse : mosquée al-Rifâ'i, AL-Khalîfa. le Caire. 
2) Sa'adiyya Rifâ'iyya : sayyid 'Alî Hamûda Khudari al-Sa'adî est le chaykh de la confrérie. Sa'ad al-Din al-Gibawî (mort en 1300) est le fondateur présumé à Damas de la Sa'adiyya (ou Gibâwiyya), confrérie dont les origines sont très obscures. On pense que la confrérie s'est répandue en Turquie et en Égypte du vivant de son fondateur. Confrérie-célèbre pour la pratique de la dosa : lors du mawled al-nabi, le chaykh de la Sa'adiyya passait à cheval sur le corps de ses disciples. Le dhikr de cette confrérie prenait des aspects extravagants qui furent interdits en 1881. Etait à la tête des processions du mahmal. Demeura respectueuse de l'autorité de chaykh al-Bakri. Le drapeau de la confrérie est vert. Le tombeau de Sîdî Yûnis al-Sa'adî al-Gabâwî alChâybâm, à qui on attribue la renaissance de la Sa'adiyya en Égypte, est à Gamâliyya, rue Nigm al-Dîn, dans la Cité des Morts située au nord de Bâb al-Nasr. Le siège de la confrérie est au 125 de la rue al-Azhar.

Les plus importantes des confréries Rifâ'iyya non reconnues :

1) 'llwâniyya Rifâ'iyya : adeptes réputés pour leurs pratiques non orthodoxes : marchent sur des clous, mangent du charbon, du verre, etc.

2) Bayt al-Wâfi al-Rifầi : sayyid Wâfi Muhammad Wâfi est le chaykh de ce groupe.

Ordre Qâdiriyya

Cette importante confrérie faisait partie de la procession du mahmal. C'est à partir de 1893 que la Qâdiriyya s'est scindée en deux, résultat de l'intervention de chaykh alBakrî dans les affaires internes de la confrérie :

1) Qâdiriyya Farîdiya ; sayyid Mas'ûd 'Abd al-Salâm Mas'ûd Higâzî est le chaykh de la confrérie, depuis février 1983. Reconnue officiellement en 1893 comme confrérie indépendante. La zâwiya de la Qâdiriyya se trouve rue aJ-Qâdiriyya dans le quartier ALKhalîfa. Adresse : 17, rue Sâmî à Mâliyya, Sayyida Zaynab.

2) Qâdiriyya Qâsimiyya : sayyid Muhammad 'Abd al-Qâdir al-Qâdirî est le chaykh de la confrérie. C'est l'ancienne Qâdiriyya qui fut renommée Qâdiriyya Qâsimiyya en 1893, d'après le nom d'un de ses chaykhs du début du xix siècle. Nombreux tekkiyés qâdiris en Égypte tekkiyés Shâykhûn et Surûgiyya). Très implantée au Soudan. Adresse :

Zagazig - Section d'al-Azhar.

Ordre Naqchâbandiyya

1) Naqchâbandiyya : sayyid Gamîl Mukhtâr Bakhît est le chaykh de la confrérie. Ordre originaire d'Asie centrale, la Naqchâbandiyya se répandit en Turquie et en Orient (Inde, Chine, Maladie), où elle est devenue un ordre orthodoxe, opposé aux manifestations extrémistes et réservé à une certaine élite. Se répandit en Égypte au début du XVIlle siède. A aujourd'hui une association de bienfaisance, la 'Gama'iyya Khayriyya Naqchâbandiyya', dont le siège est derrière l'hôpital Askû (Mission soufie, école coranique, centre d'aide sociale).

Confrérie Naqchâbandiyya non reconnue :

2) Naqchâbandiyya Khâlidiyya Gûdiyya : sayyid Isa Gûda est le chaykh de la confrérie. Adresse : rue al-Sanâdiqiyya, fundûq al-Azhar.

Mîrghaniyya Khatamiyya

Sayyid Muhammad 'Uthmân Sirr al-Khatam al-Mirghini est le chaykh de la confrérie, il travaille au ministère de l'Agricutture où il est directeur des achats et ventes. Confrérie issue de l'enseignement de Ahmad ibn Idris, originaire du Hidjaz et promoteur d'une 
réforme du soufisme conforme aux conceptions orthodoxes. Sayyid Muhammad 'Uthmân al-Mîrghinî, qui vécut et mourut en 1851 à La Mecque, où il est enterré, est le fondateur de la confrérie. Il vint au Soudan dans la seconde partie du XIXe siècle, puis en Somalie el en Ethiopie. La confrérie s'est répandue en Erylhrée, en Ethiopie, en Somalie, au Yemen, au Pakistan, en Inde el en Turquie. S'est répandue en Égypte du vivant de son fondateur. Mais, c'est au Soudan, où elle fut l'insirument privilégié de la pénétration égyptienne, qu'elle est la plus importante. La Khatamiyya a jeté les fondements de l'unité entre l'Égypte et le Soudan. Les Anglais ont proposé le trône du Soudan à sayyid 'Ali al-Mirghini en 1918, mais ce dernier a refusé, arguant qu'Égypte et Soudan formaient un seul pays. Le tekkiyé al-Mîrghinî, à Bâb al-Wazîr, est le centre de la confrérie. Adresse : 147, rue du Soudan, Imbâba.

Bakriyya ou al-Sâda al-Bakriyya

Sans chaykh, poste vacant. Sayyid Muhammad Kûbilay al-Bakri est le chaykh des sayyids al-Bakri, Se veut l'héritière de la gloire passée et de la fonction jadis dominante de la famille al-Bakri, dont les chaykhs revendiquent descendre d'Abû Bakr al-Siddîq. L'une des quatre arbâb al-sagâgîd dont l'histoire remonte au XVe siècle. Adresse : 8, rue al-'Adil Abu Bakr, Zamâlek.

Damirdâchiyya

Sayyid 'Abd al-Rahîm Mustafa ad-Demirdâsh est le chaykh de la confrérie. Muhammad Damirdâsh al-Muhammadî (mort en 1522) est le fondateur de la Damirdâshiyya.

Adresse : mosquée al-Damirdâsh.

'Abbâsiyya.

'Inâniyya ou al-Sâda al-'Inâniyya

Sayyid Muhammad 'Ali al-'Inânî est le chaykh de la confrérie. Revendique descendre de 'Umar ibn al-Khattâb. L'une des quatre arbâb af-sagâgîd dont l'histoire remonte au XVe siècle. Adresse : 17, rue Ya'qûb à Mâliyya, le Caire.

Khalîliyya

Le chaykh actuel est sayyid Muhammad Mahmûd Ibrâhîm Mahmûd Abu Khalil, résidant à Zagazig. Le fondateur de la confrérie est Mahmûd Ibrâhîm Abu al-Khalîl. Sayyid alHusaynî Abu Farha, uléma et recteur de la faculté de théologie, est membre de la confrérie. Adresse : Qism an-Nahhâl, Zagazig.

Rahîmiyya Qenâ'iyya

Ou al-sâda al-Rahîmiyya al-Qenâ'iyya : sayyid Muhammad Taha Muhammad 'Alî 'Uthmân est le chaykh de la confrérie depuis septembre 1982. Adresse : Qenâ, Lokanda al-Kamâl.

Châybâniyya Taghallubiyya

Sayyid Muhammad Gamal al-Dîn Châraf, qui est un mililaire, esl le chaykh de la confrérie, Adresse : 5, ruee aJ-Hukamâ', Manshiyat al-Bakrî, le Caire.

Autres confréries non reconnues et non affiliées à un ordre soufi

- Khiâsiyya ;

- Marwâniyya : sayyid Muhammad Yûsuf Marwân en est le chaykh.

- Tigâniyya : peu importante en Égypte. Surtout implantée au Soudan.

Enfin, il faut ajouter qu'un certain nombre des chaykhs influents, comme Abû'f-Wafâ al-Charqâwî \{mort en 1961), Ahmad Radwân de Luxor (mort en 1967), Muhammad Ahmad al-Tayyib de Gurna (mort en 1988) et Mahmûd al-'Azm (mort en 1983) n'ont 
voulu établir aucune confrérie, dédaignant de s'inscrire au Conseil supérieur des confréries soufies. Leurs adeptes sont connus commes Ahbâb al-Châykh....

\section{NOTES}

1. Delanoue (Gilbert), Moralistes et politiques musulmans dans l'Égypte du XIXe siècle, 1798-1882, Le Caire, IFAO; ainsi que l'article « Les musulmans » in L'Égypte d'aujourd'hui, permanences et changements, 1805-1976, Ed. du CNRS, 1977, Paris, pp. 26 à 43. Pour le soufisme égyptien jusqu'au XIXe siècle, on pourra également consulter : Kissling (H. J.), "The Sociological and Educational Role of the Dervich Orders in the Ottoman Empire", Studies in Islamic Cultural History, Ed. G. E. von Grunebaum, avril 1954, American Anthropologist, LV 1, 2, II Memoir n 76, New-York, pp. 23-34, exposé général des débats entre soufis et orthodoxes au cours de la domination ottomane. Moriah (Gabriel), The Social Structure of the Sufis Organizations in Egypt in the 18th Century, Thèse non publiée, Université de Londres, juin 1963. Nicholson (R. A.), The Mystics of Islam, Londres, Routledge \& Kegan, 1963.

2. Pour l'histoire de la Ahmadiyya en Egypte, voir Kummerer (E.), Die Ahmadiyya. Beiträge zur Kenntnis eines ägyptischen Derwisch-ordens, Thèse de doctorat, Tubingen, 1953, non publiée.

3. Pour l'histoire de la Châdhiliyya en Egypte, voir Bannerth (Ernst), « Aspects humains de la Châdhiiiyya en Égypte ", MIDEO, tome 11, 1972, pp. 237-250.

4. Bannerth (Ernst), « La Khalwatiyya en Égypte », MIDEO, tome 8, 1964-66, pp. 1-74.

5. Pour l'histoire de la Khalwatiyya en Egypte, se référer à : Martin (B. G.), "A Short Story of the Khalwati Order of Derviches", in Keddie Nikki, Scholars, Saints and Sufis. Muslim religious Institutions in the Middle East since 1500, Berkeley/Los Angeles, 1972, pp. 275-305.

6. Se référer à Bannerth (Ernst), « La Rifâ'iyya en Égypte », MIDEO, tome 10, 1970, pp. 1-35.

7. Al-Manâr, vol. VII, 15th july 1904, pp. 331-332.

8. voir Liwâ' Islâmi, 27 octobre 1988, page 3.

9. Voir De Jong (Fred), Turuq and Turuq-linked Institutions in XIXth century Egypt : a Historical Study in Organsational Dimensions of Islamic Mysticism, Leiden, EJ. Brill, 1978. Cet ouvrage, qui s'attache notamment à retracer l'histoire de la famille al-Bakrî, fournit une étude détaillée des débuts du processus d'institutionnalisation du soufisme en Egypte. Pour le début de ce processus, se référer à AL-TAWIL (Tawfîq), Al-tasawwuffi Misr ibbâna al-'asr al-'Uthmàni (Le soufisme en Egypte durant la domination ottomane), Maktaba al-Adâb, le Caire, 1946. De Jong (Fred), « Les confréries mystiques musulmanes au Machrek arabe ", Les ordres mystiques dans l'islam, Travaux publiés en 1986 sous la direction de A. Poppvic et G. Veinstein, EHESS, Paris, pp. 205-243. Taftazani (Abû-l-Wafa al-Ghunaymî), Al-turuq al-sûfiyya fi Misr (Les confréries soufies en Egypte), Université du Caire, Bulletin of the Facurty of Arts. 25, part. Il (1963), publié en 1968, pp. 55-84

10. Voir le texte de la loi de 1903 in 'Uways (Sayyid), Al-ibdà' al-thaqâfí 'alà-l-tariqa al-misriyya : dirâsa 'an al-qaddisîn wa-l-awliyà fí Misr (Etude des saints chrétiens et musulmans en Egypte), Dâr al-Tibâ'a al-Haditha, le Caire, 1981, pages 131 à 135.

11. Idem pour le texte de la toi de 1905, pages 137 à 149 .

12. Magallat al-lslâm wa-l-Tasawwuf, revue du Conseil soufi, octobre 1959.

13. Qanûn raqm 118 li-l-sana 1976 bi-sha'n nizâm al-turuq as-sûfiyya. Al-Jarîda al-Rasmiyya n 37 , 11 septembre 1976. Traduction française de cette loi à paraître dans le $\mathrm{n}^{0} 3$ de Égypte/Monde arabe (3e trimestre 1990), CEDEJ, le Caire. 
14. 'Al-lâ'iha al-tanfidhiyya", Al-Jarîda al-Rasmiyya nº 9. 2 mars 1978. (Traduction française : voir op. cit. note 14).

15. Tasawwuf Islâmi, revue du Conseil supérieur des confréries soufies, $\mathrm{n}^{\circ} 34$, janvier 1982, page 9.

16. Lane (Edward William), Manners and Customs of the Modem Egyptians, 1833- 1835, Londres, EastWest Publications, 1989.

17. Akhbâr al-Yawn, 25 décembre 1971, page 12. Mac Pherson (J.W.), The muwlids of Egypt, Le Caire, 1941.

18. Muhammad (Su'âd Mâhir), Masâgid Misr wa awliyâhâ al-sâlihûn (Mosquées et saints en Egypte), Le Caire, 1971.

19. 'Uways (Sayyid ), Min malâmih al-mugtama' al-misn al-mu'âsir. Zâhira irsâl al-rasâ'il li darîh alimâm al-Châfi'i (Le phénomène du courrier adressé au tombeau de l'imam Châfi'i), Etudes sociologiques CNRSC, CAIRO, 1965; seconde édition, Le Caire-Koweit, Dâr al-chàye' li-l-nachr, 1978.

20. Mustafa (Farûq Ahmad), Al-mawâlid, dirâsa li-l-'âdât wa-l-laqâlîd al-cha'biyya fî Misr (Les mawlid, étude des traditions populaires en Egypte), Al-hayy'a al-'amma li-l-kitâb, Alexandrie, 1980.

21. Berger Morroe, Islam in Egypt today. Social and political aspects of popular religion, Cambridge University Press, Londres, 1970.

22. 'Uways (Sayyid), Al-ibdâ' al-thaqâfí..., op. cit.

23. Heyworth-Dunne (J.), Introduction to the History of Education in Modem Egypt, Luzac and $C^{\circ}$, Londres, 1938.

24. Anawati (G. C.) et Gardet ( L), Mystiques musulmanes, Vrin, Paris, 1961.

25. Bannerth (Emst), op. cit.

26. Gilsenan (Michael ), Saint and Sufis in modern Egypt. An essay in the Sociology of religion, Clarendon Press, Oxford, 1973. Voir également : "Some Factors in the Decline of the Sufi Orders in Modern Egypt", The Muslim World, n067, 1967, pp. 11-18.

27. Trimingham (J. Spencer), The Sufi Orders in Islam, Clarendon Press, Oxford, 1971.

28. Meier (F.), « Soufisme et déclin culturel », in Clacissisme et déclin culturel dans l'histoire de l'islam, R. Brunschvig and G. E. von Grunebaurn éd., Paris, 1957.

29. 'Abd al-Mawgud (Mahmûd 'Abd al-Rachid), Al-tanzîmàt al-sûfiyya wa dawruhâ fì tanmiya almugtama' (Le rôle des organisations soufies dans le développement économique et social), Thèse de doctorat non publiée, Université de Minya, 1989.

30. 'Abd al-Latif (Muhammad Fahmî), Al-ayyid af-Badawî wa dawlat ad-darâwîch fî Misr (Sayyid alBadawî et l'État des derviches en Egypte), Manchûrât Samîr Abu Dâwûd - Al-markaz al-'arabî Iilsahàfa, 1948; seconde édition 1979, le Caire.

31. Voir la série d'articles dans Al-Liwà' al-Islâmi, consacrés à la question de la transmission héréditaire de la fonction de chaykh soufi, 2 mars 1989, page 5, 8 juin 1989, page 5, et 22 Juin 1989, page 5. Pour un récapitulatif des critiques salafistes envers les confréries soufies, se référer à : Hilmi Mustafâ, Al-tasawwûf wa al-ittigâh a/-sa/afi fi al-'asr al-hadîth (Le soufisme et le courant salafiste à l'époque moderne), Dâr ad-Da'wa, Alexandrie, 1982.

32. idem, 22 juin 1989, page 5 .

33. Warburg (G.) \& Kupferschmidt (U.M.), Islam, nationalism and radicalism in Egypt. 1907-1970, Praeger Publishers, New-York. 1983; voir l'article de Fred De Jong, "Aspects of the Political Involvement of Sufi Orders in 20th century Egypt", qui fournit l'histoire détaillée des rapports entretenus par certaines confréries avec les pouvoirs égyptiens successifs au XXe siècle, pp.

183-212.

34. Ahmad (Raf'at Sayyid), Al-dîn wa-l-dawla wa-l-thawra, (La religion, l'État et la révolution), Dâr al-Charqiyya, Le Caire, 1989. 
35. 'Ilwan (Muhammad Mahmûd), “Al-tasawwuf al-islâmî. Al-machyakha al-'amma li-l-turuq alsûfiyya", Magallat al-islâm wa-l-tasawwuf, le Caire, septembre 1958, pp. 3-6 (Le chef suprême des confréries soufies de l'ère nassérienne expose ses conceptions et les raisons de son soutien au régime.)

36. Al-Muslim, revue de la 'Achira Muhammadiyya, juin 1964.

37. Voir à ce propos l'article de Maghreb-Macnrek n 130, 4e trimestre 1990 : P.-J. Luizard, « Le rôle des confréries soufies dans le système politique égyptien ».

38. Maghreb-Machrek $\mathrm{n}^{\circ} 130$, op. cit.

39. Al-Ahrâr, 7 avril 1986, page 4 .

40. Al-Liwâ' al-Islâmi, 19 janvier 1989, page 5 .

41. idem. 16 juillet 1987, page 6. -10 novembre 1988, 14, 15, 16, 17.- 27 octobre 1988, page 3.- 3 novembre 1988, page 3.

42. Al-Akhbâr, 9 décembre 1988, page 6 .

43. Al-Liwâ' al-Islâmî. 23 février 1989, page 4.

INDEX

Mots-clés : islam, religion, soufisme, mawlid

\section{AUTEUR}

PIERRE-JEAN LUIZARD

CNRS-CEDEJ 